\title{
Survival, Social Cohesion and Rock Art: The Painted Hands of Western Arnhem Land, Australia
}

\author{
Sally K. May ๑, Luke Taylor, Catherine Frieman, Paul S.C. Taçon, \\ Daryl Wesley, Tristen Jones, Joakim Goldhahn \& Charlie Mungulda
}

\begin{abstract}
This paper explores the complex story of a particular style of rock art in western Arnhem Land known as 'Painted Hands'. Using new evidence from recent fieldwork, we present a definition for their style, distribution and place in the stylistic chronologies of this region. We argue these motifs played an important cultural role in Aboriginal society during the period of European settlement in the region. We explore the complex messages embedded in the design features of the Painted Hands, arguing that they are more than simply hand stencils or markers of individuality. We suggest that these figures represent stylized and intensely encoded motifs with the power to communicate a high level of personal, clan and ceremonial identity at a time when all aspects of Aboriginal cultural identity were under threat.
\end{abstract}

\section{Introduction}

There is a great duality to the humble human hand in rock art. In one way, it is deeply personal, a kind of memorialization of the individual. Yet in another way it is one of the very few 'universal symbols' in rock art, being found in many parts of the world, spanning vast time periods and cultural contexts, representing our shared humanity. The human hand has been added to rock surfaces in Australia for tens of thousands of years, primarily in the form of prints and, more commonly, stencils which seem to appear in the earliest as well as the more recent rock-art traditions (e.g. Chaloupka 1993; Layton 1992; Morwood 2002; Veth et al. 2018). While rock-art styles and certain depicted subject matter came and went, the human hand figure held its ground. Then, sometime during the late nineteenth or early twentieth century in the midst of dramatic changes to Aboriginal life in western Arnhem Land, something changed. While the standard hand stencilling continued as before, a new style of highly decorated and elaborated hand figures emerged and multiplied for a short period of time-the Painted
Hand style (Fig. 1). In this paper, we explore these changes and the possible motivations behind them.

Artefacts have the remarkable ability to not only reflect periods of stress within and between different societies, but to also play an active role in assisting these groups actively to navigate these experiences. As Hodder $(1979,450)$ suggests, 'When tensions exist between groups, specific artifacts may be used as part of the expression of within-group corporateness and "belongingness" in reference to outsiders'. If we accept the premise that, in times of stress, we may see an increase in the production of symbols of identity, then it follows that sudden, obvious shifts in style evidenced in the archaeological record may indicate such traumatic episodes.

In this paper, we argue that a new style of rock art (Painted Hands) emerged in response to contact, and specifically to changes occurring in Aboriginal life as a result of new interactions in the historical period. This suggests that the Painted Hands are more than simply hand stencils or markers of individuality (Fig. 1). As we will argue and demonstrate, they represent stylized and intensely encoded motifs with the power to communicate a high level of 


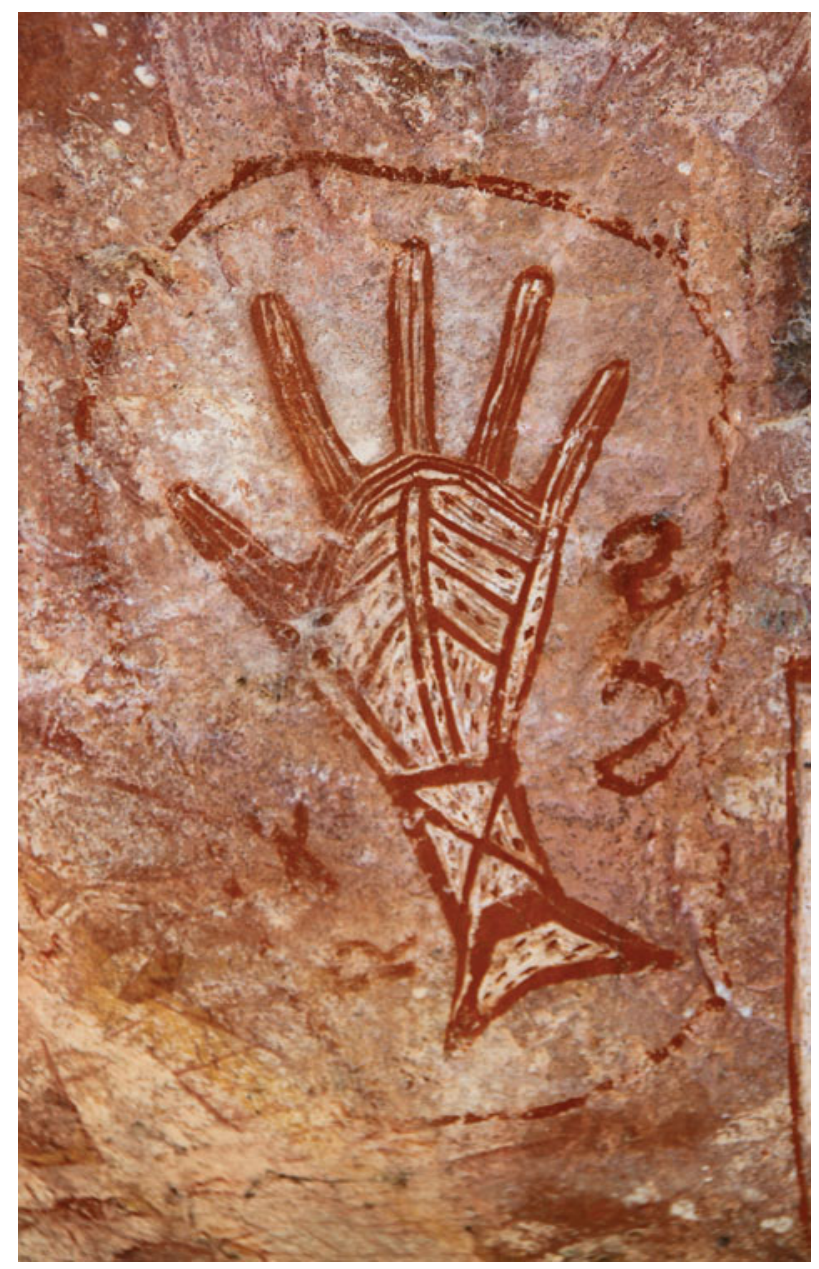

Figure 1. One of the Painted Hands at Awunbarna. (Photograph: Paul S.C. Taçon, 2018.)

personal, clan and ceremonial identity at a time when all aspects of Aboriginal cultural identity were under threat.

\section{Innovation in rock art}

This study builds upon the vast literature surrounding archaeology, art and the impetus for change. For example, Wiessner (1983) argues that situations likely to invoke a strong sense of group identity are those where people are fearful, where there is intergroup competition, or situations where there is a need for co-operation to attain social or political or economic goals. Colonialism, invasion, dispossession and war dominate such discussions (e.g. Dowson 1994; Troncoso \& Vergara 2013).

Patricia Crown's (1994) study of the emergence of polychrome Salado pottery in the American southwest during the thirteenth and fourteenth centuries
AD offers a somewhat contrasting but still related example. This period saw considerable migration events, possibly due to warfare and drought, leading to the breakdown of kin networks and associated ritual structures. She argues that the polychrome decorative tradition emerged as part of a broader hybrid identity, perhaps consciously adopted by migrants as a strategy to develop worthwhile materials or skills in order to fit better into new communities and supplement farming as a source of subsistence, since farm land available to migrants was probably poor (Crown 1994, 213). In other words, in a context of demographic pressure and cultural breakdown, new styles were operationalized to promote peaceful co-existence among newly adjacent populations.

Innovation in an archaeological context, like our Painted Hands, is regularly framed as a quasi-automatic, functionalist or evolutionary process through which less efficient or adapted materials, ideas or technological systems are replaced by more efficient or better suited ones. However, this process is actually deeply embedded in social interactions and tied to larger social and material spheres (Bijker 1995; Lemonnier 1992; Pfaffenberger 1992; Rogers 2003; Torrence \& van der Leeuw 1989). Not only is the impulse to innovate or to accept an innovation socially conditioned, but the desire for a new object, practice or technology develops out of a preexisting process of learning about and testing it (Rogers 2003; Rogers \& Shoemaker 1971).

The emergence of new rock-art styles in western Arnhem Land has commonly been associated with changes in environmental conditions. This is most obvious in the overarching chronology developed by George Chaloupka (1993), who directly links rock-art styles to environmental transformations (for example, X-ray art is placed within the Freshwater period, Dynamic Figure rock art within the Pre-estuarine). Indeed, archaeologist Rhys Jones suggested in the 1980s that competition for resources led to an increased marking of territory and differentiation between groups evident in aspects of cultural life (Jones 1985, 293-4).

Of the more recent rock art, Chaloupka (1985) and Jones $(1985,291-4)$ argue that Complex X-Ray rock art was produced as a response to an increase in population size which itself was the result of environmental change. Over the last two decades, demographic pressure has become a central focus of evolutionary archaeological models of innovation and technological change (e.g. French 2016; Powell et al. 2009; Shennan 2001). These models view increasing population size and connectivity as key 
causal factors in the development of new and more complex technologies, which themselves are understood to help human populations relieve and respond to demographic pressure and environmental constraints. As June Ross $(2013,165)$ notes in her pan-Australian study of regionally distinct rock-art styles, 'alterations noted in the archaeological record such as the introduction of a new art style are viewed as adaptive strategies aimed at ameliorating changing ecological conditions'. These models have, however, come under increasingly heated critique, particularly from Australian archaeologists, as many are premised on outdated and colonialist understandings of Aboriginal Australian (and particularly Tasmanian) society and material culture (Collard et al. 2016; Frieman in prep; Henrich 2004; Vaesen et al. 2016).

Indeed, Ross $(2013,165)$ also suggests there is more to this story than just adaptation to environmental change. She argues that:

each of the varied art assemblages were introduced at a time when the relationship between people and place was under pressure, whether the pressure came from outside intruders, rising sea levels, population increase or the introduction of more intense interaction in the form of trade networks, or a combination of these factors.

Likewise, others, such as Bruno David and colleagues (David \& Chant 1995; David \& Lourandos 1998; 1999) have also argued for a primarily sociocultural context influencing change in the archaeological record.

How, then, may this be reflected in rock art produced during the recent past in Australia? Colonialism impacted upon existing rock-art traditions Australia-wide in various ways. Some groups were so impacted by violence, incursions into their land and forced movement that they all but ceased rock-art production (Mulvaney 2018; Taçon et al. 2012, 428), while others were drawn to connect with their rock-art traditions in new ways, such as by re-working earlier rock-art imagery (Taçon $e t$ al. 2008). Still others engaged with the new subject matter, depicting introduced material culture and animals, as though reflecting on its significance (May et al. 2017b); while, at the same time, they continued to produce more traditional motifs long after the novelty of these new subjects had run its course in rock art (Frieman \& May 2019; May et al. 2010; 2019).

Despite the evident capacity of Australian rock art to reflect major changes-both social and environmental-impacting on human society, the production of rock art is typically discussed in the context of the maintenance of traditional practices with emphasis on the continuity of long-term trends (i.e. Chaloupka 1993). In fact, as recent research on contact rock art has shown (see Goldhahn \& May 2019 for an overview) and as argued by Frieman and May (2019), Australian historical-period rock art reveals a dynamic, socially embedded series of practices which allowed new ideas, new materials and new ways of seeing the world to be examined, interrogated and selectively adopted into preexisting social structures and practices.

\section{The Painted Hands of western Arnhem Land}

Painted Hand rock art has attracted the attention of researchers for some time due to its vividness at particular sites. Many Painted Hands have complex design elements not seen in other rock art. For this study, we define Painted Hand rock art as:

- The representation of an anatomically correct human hand, wrist and, sometimes, forearm by stencil, outlining or painting of the shape.

- These figures are then infilled with painted design features of varying complexity (e.g. Figs. 1 and 2).

- Some figures are also encircled by a line (e.g. Figs. 1 and 3).

\section{Previous research}

Painted Hands often feature in illustrations relating to western Arnhem Land rock art (e.g. Brandl 1973, 169, fig. 63; Mountford 1956, 178, pl. 48), but have rarely been the topic of any deeper analysis. We focus here on the authors who attempted to interpret this unique rock art, rather than the many times Painted Hand figures were used for illustrative purposes only.

Jan Jelínek deserves special mention for his documentation of many Painted Hands and brief discussions of them in his many publications relating to Arnhem Land (e.g. Jelínek 1976; 1977; 1989). Yet it was George Chaloupka (1993) who offered the first detailed interpretation of their emergence. He also defined their geographical distribution, arguing that they were found from 'the northern outliers of the Wellington Range at the base of the Cobourg Peninsula to the Oenpelli and Ubirr-Canon Hill region, with occasional individual representations being found elsewhere along the northern and western margins of the plateau' (Chaloupka 1993, 214). In terms of clan lands, he states they are found predominantly in the estates of the Amurdak-speaking 


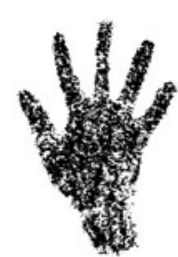

MN01 - Motif 1

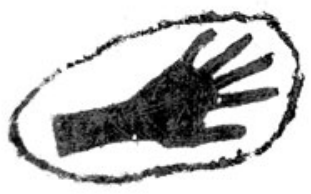

MNO1 - Motif 2

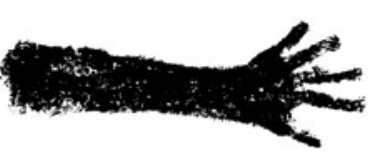

MNO1 - Motif 3

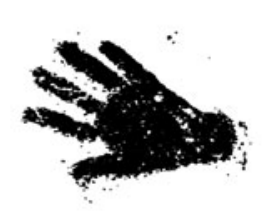

MN01 - Motif 5

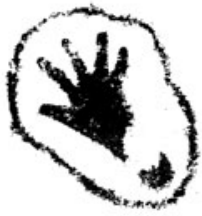

MN01 - Motif 6

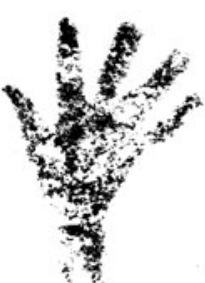

MNO2 - Motif 1

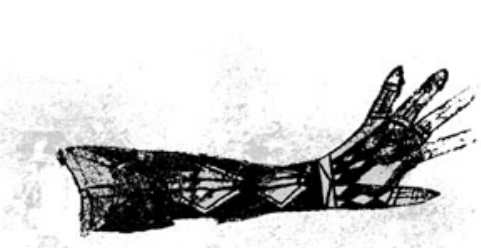

MN15 - Motif 2

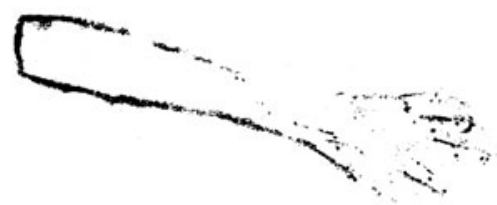

RLLO3 - Motif 1

MNO5 - Motif 2
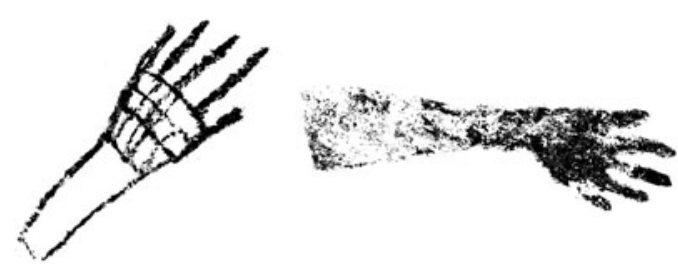

MNO5 - Motif 5

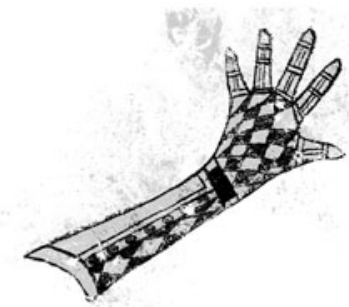

MN15 - Motif 3

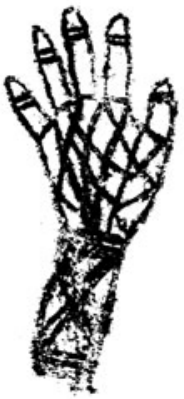

RLLO3 - Motif 2

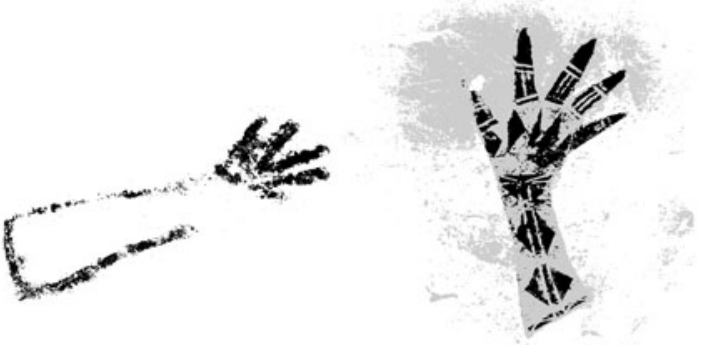

MNOS - Motif 6

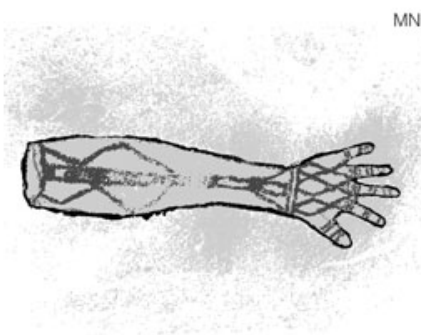

MN15 - Motif 4

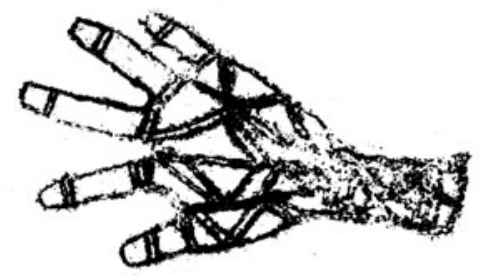

RLL03 - Motif 3

Figure 2. Digital tracings of some of the Painted Hands from Minjnymirnjdawabu. (Photographs: Tristen Jones. Tracings: Meg Walker.)

groups, who had ritual ties to the Iwaidja and Garrig people to the north on the Cobourg Peninsula.

Chaloupka argues that this type of rock art was originally inspired by the gloves worn by European women at the Victoria Settlement in the early 1800s. He claims that he was told this by Galardju elder Namadbarra (Paddy Compass Namatbara) (Chaloupka 1993, 214). Variations in the design elements were argued to reflect the design of the original glove with some featuring 'lace-like quality' and others representing 'pieces of leather forming a glove'. In other cases, he argues the designs represent the anatomy of the actual hands with life-lines and nails depicted (Chaloupka 1993, 214).

Tellingly, Roberts and Parker (2003) do not reiterate this interpretation in their book focusing on the rock art of Awunbarna (Mt Borradaile), the area Chaloupka $(1993,214)$ suggests is the epicentre 

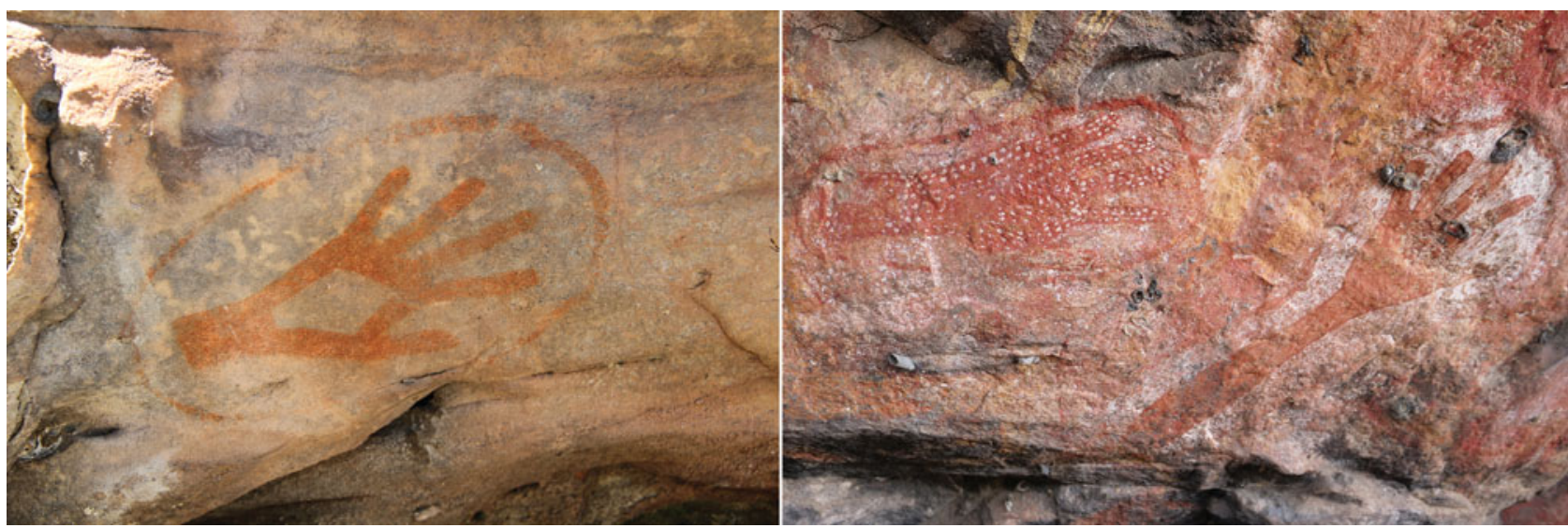

Figure 3. Examples of encircled Painted Hands from Awunbarna. (Photographs: (left) Paul S.C. Taçon, 2018; (right) Sally K. May, 2019.)

for this type of painting. Instead, they present photographs of key examples of the main shelters where Painted Hand figures occur and offer occasional information on their design. For example, in the caption to one photograph they state:

Decorated hand stencils, one with Reckitt's Blue, overlying layers of figurative art in the Major Art habitation shelter. A number of the hand stencils have borders around them in what is possibly an attempt to distinguish them from their immediate environment. Unusually, the hand stencil on the bottom left has two borders around it. (Roberts \& Parker 2003, 32)

They offer no further attempt at interpretation. Their use of the term 'frame' in the caption to another photograph (Roberts \& Parker 2003, 33) is perhaps inspired by Chaloupka's $(1993,214)$ discussion of this design element, where he argues that this design feature focuses attention on the image, just as a European picture frame would, and that the artists may have been inspired by framed pictures seen at nearby settlements. Furthermore, Chaloupka (1993, 214) suggests that the frame may compensate for the loss of the 'distinguishing contours' of the artist's hand as the stencils were infilled with design elements. The frame, he argues, could be an attempt to retain individual identity and 'emphasised the artist's presence and identified his work' (Chaloupka 1993, 214).

It is worth noting that a number of researchers have associated the Painted Hands with broader styles. This includes 'Complex x-ray' (Brandl 1973, 168-9), 'Decorative X-ray' (e.g. Chaloupka 1983, 14) and 'X-ray II' (Haskovec \& Sullivan 1986, 30). Chaloupka $(1983,13)$ suggests that the Decorative
X-ray style followed the Descriptive X-ray style, moving away from a focus on internal elements of the subject-matter and more towards 'decorative expression' (see also Haskovec \& Sullivan 1986, 29). As discussed below, we do not believe the Painted Hands incorporate X-ray design elements and we therefore argue that they have been misplaced in these broader stylistic categories.

Paul S.C. Taçon recorded a fascinating discussion with Bill Neidji regarding Painted Hands during his 1980s fieldwork. He states that 'Some stencils have been painted with clan designs and $x$-ray features, such as finger bones, to produce striking images by which to honour and remember particular individuals' (Taçon 1989a, 138). Neidji informed him that after people die their spirits watch over their 'finger prints' (hand or hand-arm stencils); and, if someone paints the stencils, the spirits will say you are a good man. Likewise, if someone were to rub the stencil off the wall, the spirit might make you sick (Taçon 1989a, 138). As discussed below, Neidji himself was responsible for the design elements within an existing hand and arm stencil made at Amarrkanangka (Cannon Hill) in the 1930s (Taçon 1989b, 25, fig. 34).

Charles Mountford, visiting in 1948, also describes a stencil of the hand of a small girl who had since died at Amarrkanangka (Fig. 4). He states that 'It has been decorated with attractive herringbone designs' (Mountford 1956, 178, pl. 48G). While it is unclear if the designs were added later, it does appear to be further evidence of the original stencil and designs occurring at different times for some Painted Hands.

It is worth noting Chaloupka's discussion of the significance of hand stencils generally, as it 


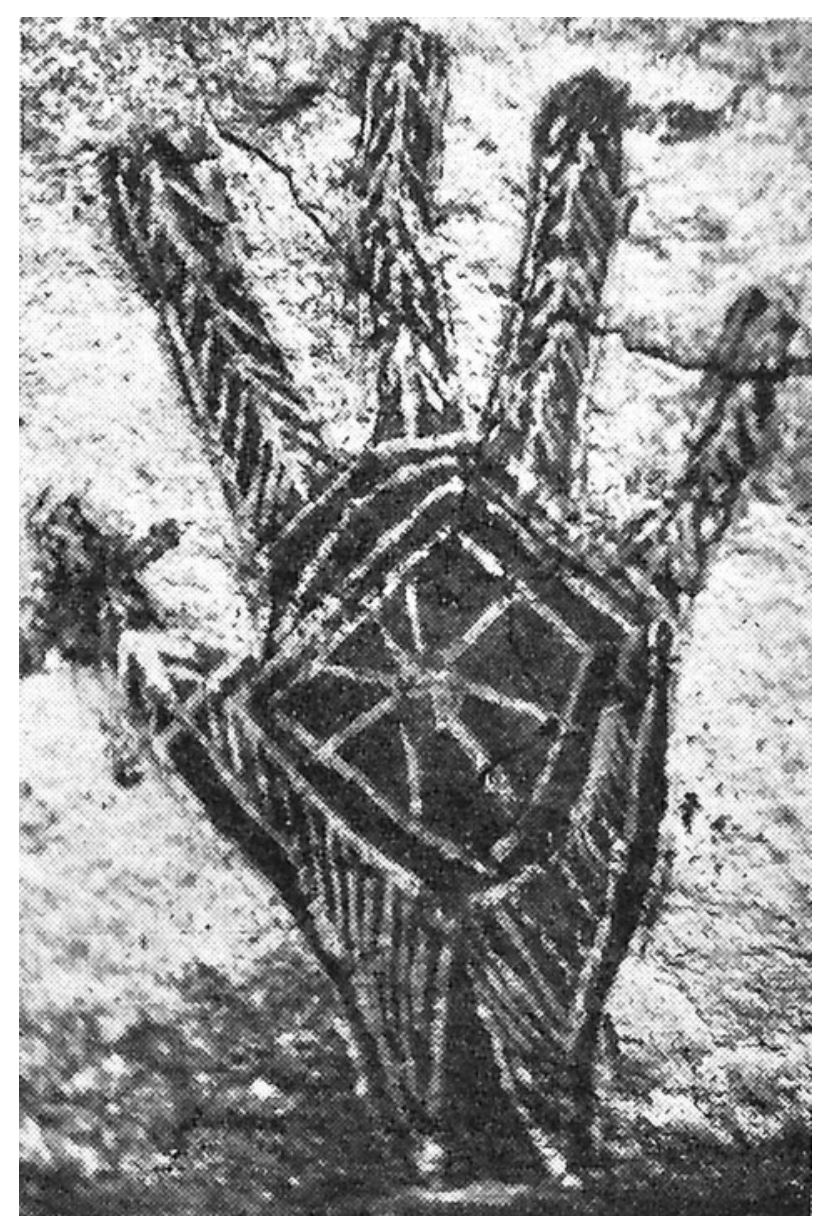

Figure 4. Painted Hand at Amarrkanangka. (After Mountford 1956, 178, pl. 48G.)

relates to ideas of personal identity touched upon in this paper. He states: 'Almost every person of that generation knew the localities of their own hand stencils and could identify those belonging to others. Some people made stencils of their hand a number of times during their lifetime, in many instances in estates other than their own' (Chaloupka 1993, 232).

Chaloupka argues that the main function of stencils was to record a visit to or association with a particular place, but they were also used to 'sign' other paintings. He gives the example of Narlim, a Mengerrdji man who painted a sailing vessel at Warlkarr shelter (Aamarrkananga) and signed his name across the hull of the ship. In addition, Narlim 'also left a stencil of his hand by which he was remembered by those who could not read' (Chaloupka 1993, 232-3). These examples illustrate the very personal and individual nature of hands in rock art in western Arnhem Land.

\section{Links to ceremony}

Taçon (1989a, 339) associates Painted Hands with death rituals and the Lorrkon ceremony. He states that designs painted on log coffins, human skulls, and on hand or hand and arm stencils contain Rainbow Serpent power associated with Ancestors and help return the dead to clan wells. This corresponds with his example of Neidji painting the hand stencil of a recently deceased woman.

While each of the ceremonies in western Arnhem Land are distinct on the basis of their primary purpose, the link between an individual and their clan country is a common theme. For this reason, people see their multiple ceremonies to be linked into a set for initiation and mortuary purposes (Taylor 1996). For example, Lorrkon addresses the final reburial of a person's bones and the journey of their spirit to important sites in their country. The Mardayin ritual celebrates the spiritual connection of new initiates to their clan lands and to the sacred objects of the clan. As a related theme, Mardayin addresses the issue of the transmission of sacred objects owned by the deceased persons to new senior people. Thus, Lorrkon and Mardayin are considered to be linked in relation to mortuary issues and in respect of the journey of a human soul from the deceased to their clan waterhole where, in turn, the soul can be reborn to new members of the clan. Other features of Mardayin are concerned with the more general release of Ancestral power to ensure the replenishment of the multiple species of the world.

A core theme for all ceremonies is the enduring relationship between particular Ancestral beings, the country created by them and the spiritual connection of individuals to this Ancestral template. However, changes in ceremonial performance are also a feature of the internal dynamics of western Arnhem Land societies. Ceremonies of the same name may vary depending upon the context of where they are held and who is in attendance. Visiting groups may be incorporated, or the presence of new settling groups may lead to more permanent ceremonial change. Respected ceremonial leaders can work with their peers to vary performances to account for different circumstances and to incorporate ceremonial innovations.

The contention of this paper is that such internal processes of change were vastly exacerbated by historical changes wrought by culture contact and colonization processes. Ceremonial change is an important mechanism for adjusting the relationships between groups of people who are moving across the lands of others, or moving to live relatively permanently in new settlements. Changes in the relative 
Figure 5. The Painted Hand (red outlined with cross-pattern design) created by Djimongurr (Old Nym) and his son Namandali (Young Nym) near the Koongarra Saddle. (Photograph: Joakim Goldhahn.)

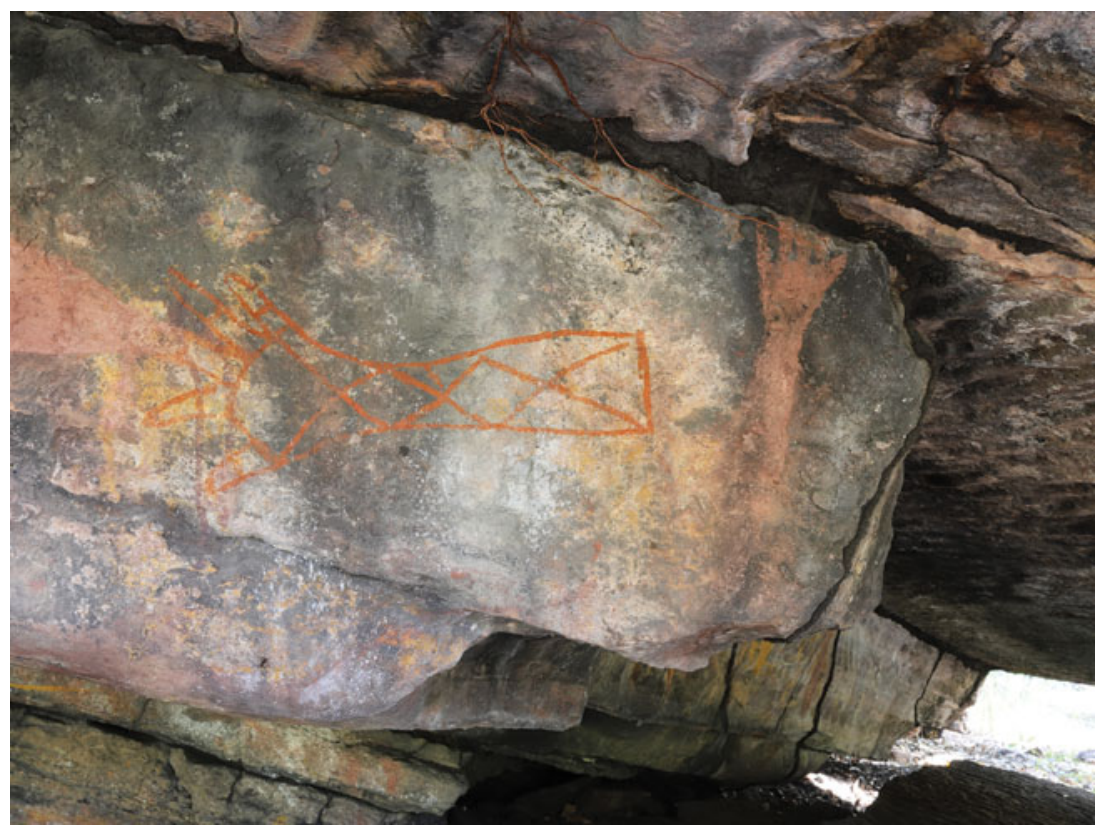

Figure 6. From left to right: Raburrabu (Mission Jack), Nayombolmi (Barramundi Charlie), Toby Gangale and Djimongurr (Old Nym), c. 1960. (Photograph: Judy Opitz Collection.)

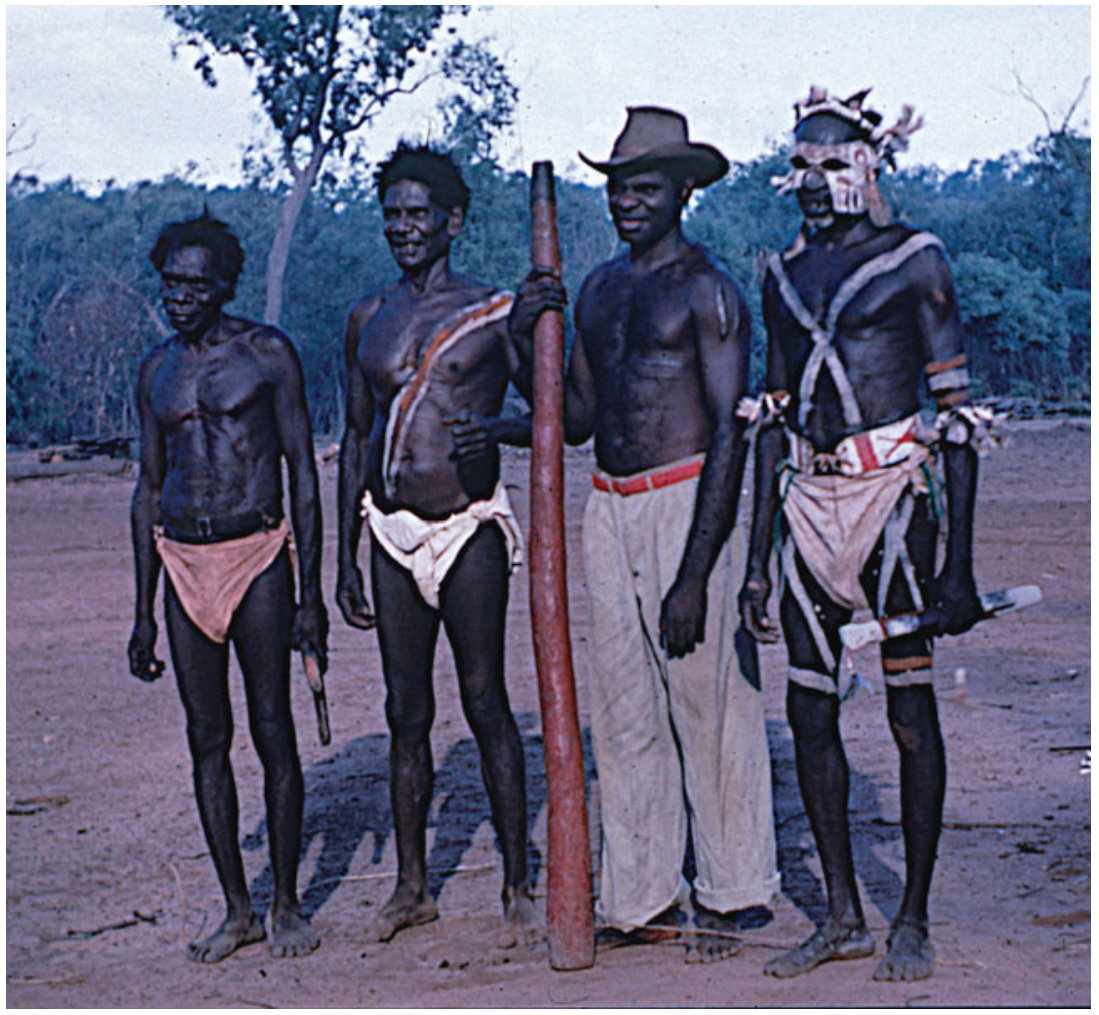

importance of different ceremonies, introductions from other regions and the coalition of elements from distinct ceremonies into new amalgams have all been documented over the last 100 years in the region (e.g. Berndt \& Berndt 1970; Garde 2011; Taylor 1996). This is true even as the intimate spiritual links between people and the Ancestors that made the lands is a central concern. Over the 


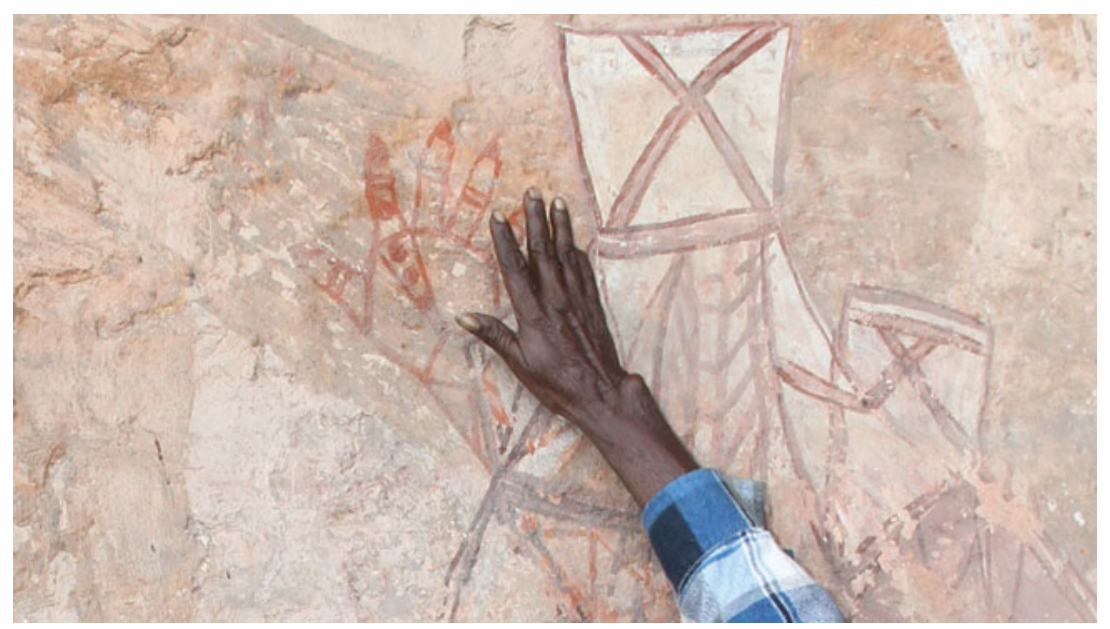

Figure 7. Josie Maralngurra with her Painted Hand at Nanguluwurr.

(Photograph: Paul S.C. Taçon, 2019.)

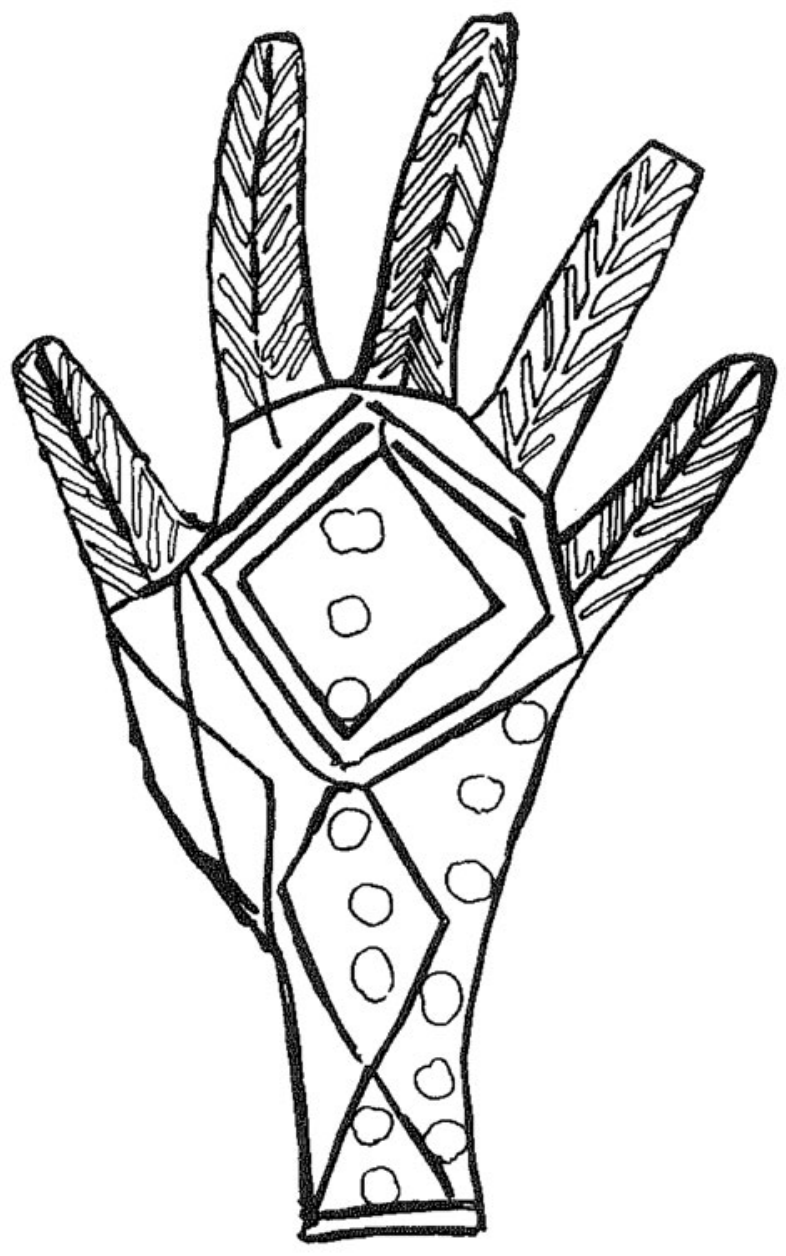

Figure 8. Painted Hand by Nayombolmi, Deaf Adder Gorge, Kakadu. (Brandl 1973, 31, fig. 63.) generations, people can gain spiritual links with new lands through learning about them, having rights bestowed by landowners in ceremonial contexts, and through the life-cycle of death and conception of children in the new lands.

Transformation in ceremonial practice links with this wider incorporation of change. For example, major regional performances of Mardayin became less important by the late 1960s in western Arnhem Land, although the use of Mardayin body paintings continued in the context of circumcision ceremonies in some areas. Knowledge by artists of Mardayin body paintings and objects also stimulated much experimentation in bark paintings made for sale from the 1970s to the present (Taylor 2015; 2017).

We would argue that the Painted Hands represent a similar efflorescence, albeit at an earlier date and in a different context. The paintings are innovative productions as the artists respond to changed circumstance and the works create new meaning through the combination of elements that have established reference in other contexts of use.

\section{Chronology}

There are a number of factors that come together to suggest Painted Hands were produced in the historical period. First, we have four first-hand accounts of them being created. Famous rock painter Djimongurr (Old Nym) and his son Namandali (Young Nym) produced a painted hand in the Koongarra Saddle area of Kakadu in the late 1950s or early 1960s (Figs. 5 \& 6). This evidence comes from Djimongurr's daughter Josie Maralngurra who was with him at the time and witnessed the event (May et al. 2019). At Nanguluwurr, Josie's father also created a Painted Hand from her own hand stencil in 
Figure 9. A Painted Hand at Amarrkanangka with infill design by Bill Neidjie. (Taçon 1989b, 25, fig. 34.)

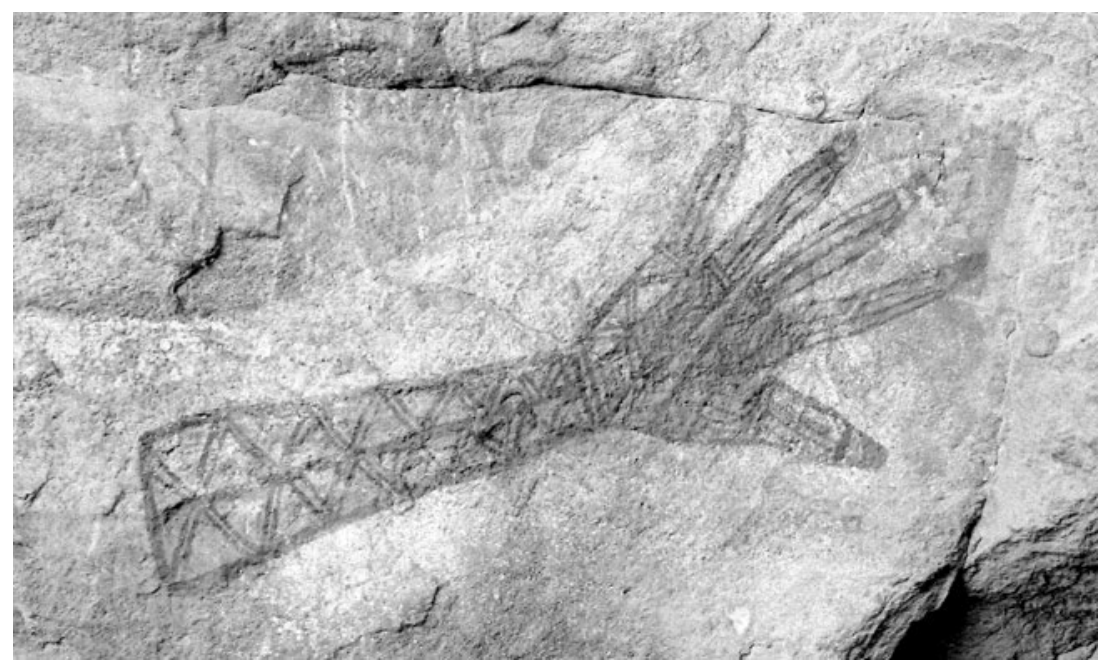

early 1964 when she was about 12 or 13 years old (Josie Maralngurra pers. comm., 2019; Fig. 7), a date confirmed by earlier research of painting episodes at the site by Chaloupka (1982, 27-30), Haskovec \& Sullivan (1986) and Taçon (1989a: 49).

Djimongurr's long-time friend and artistic collaborator Nayombolmi (Fig. 6, also known as Barramundi Charlie) created a Painted Hand in the Balawurru area (Deaf Adder Gorge) with evidence coming from his cousin Nipper Kapirigi, who identified it as his work to Taçon in the 1980s (Fig. 8; see also Haskovec \& Sullivan 1986; 1989). The final (aforementioned) example was created by Bill Neidjie at Amarrkanangka in the 1940s (Taçon 1989b, 25, fig. 34 caption; Fig. 9).

Another insight into the age of Painted Hands comes from the incorporation of pigment made using laundry-whitening cubes such as Reckitt's Blue (Fig. 10). Reckitt's Blue was 'borrowed' from local settlements, such as Oenpelli, for use as a pigment for painting on rock, bark and a variety of objects (e.g. Chaloupka 1979; 1982; 1993; Haskovec \& Sullivan 1986; Roberts 2004; Taçon 1989a). It was most likely made available via the Kaparlgoo Native Industrial Mission (c. 1899-1903) or Oenpelli settlement (1910-present) and, as such, gives us a terminus post quem for these particular images.

Moreover, Painted Hands are almost always the most recent layer of art at sites. Only three in our sample were overpainted-one by a horse (Fig. 11) and the other by a sailing vessel, and the third by a barramundi (Fig. 7). The later Painted Hand, however, was made by Djimongurr during the same visit to Nanguluwurr in early 1964 (Josie Maralngurra pers. comm., 2019).

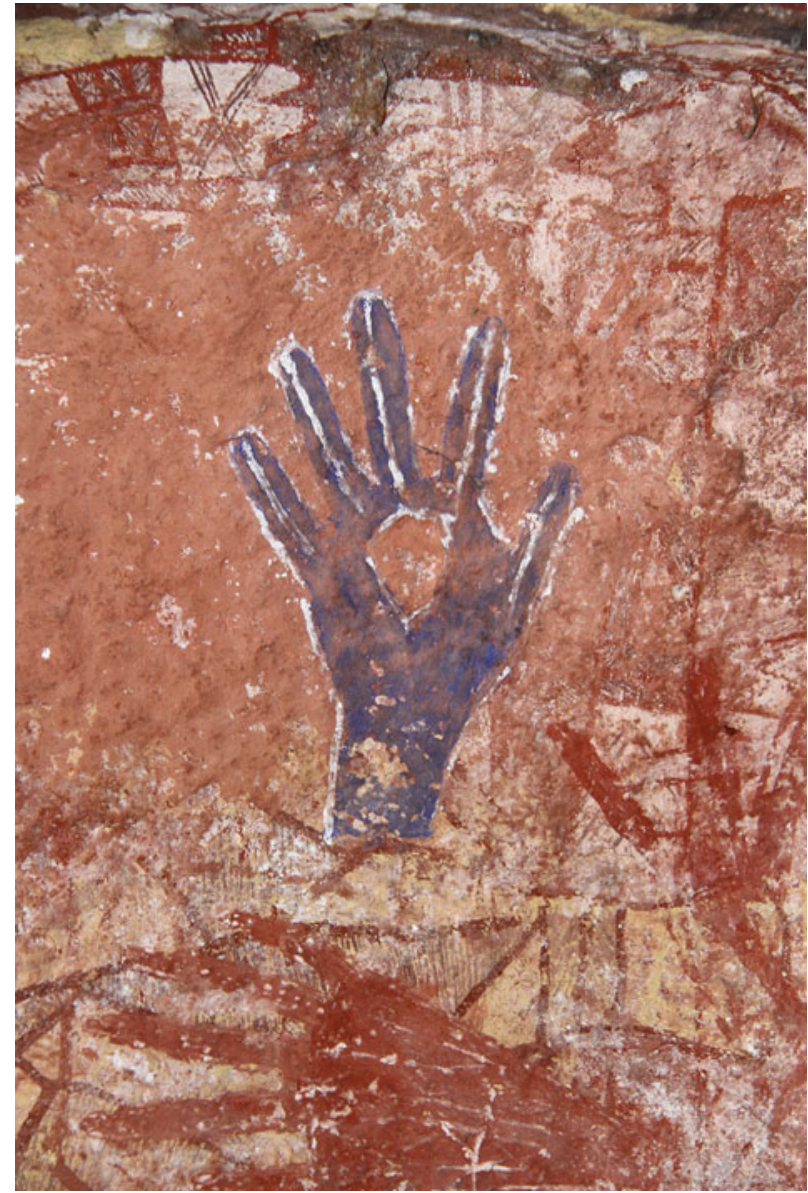

Figure 10. Reckitt's Blue Painted Hand from Awunbarna. (Photograph: Paul S.C. Taçon, 2018.) 


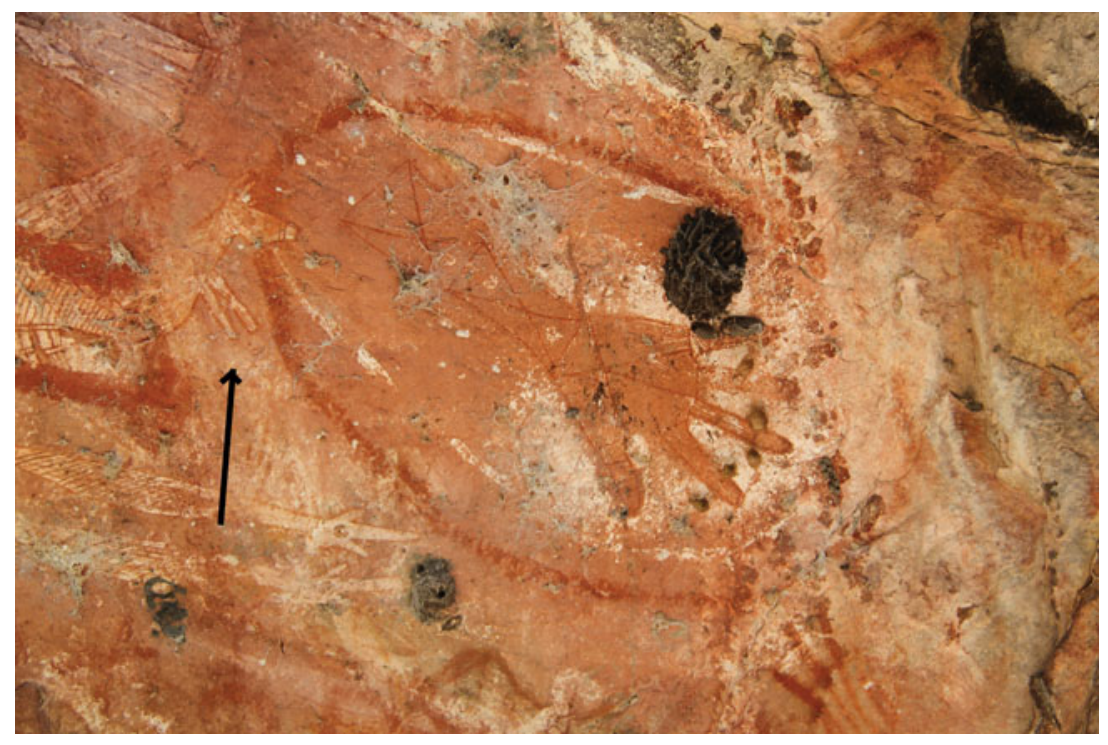

Figure 11. Small painting of a horse over the circle surrounding a Painted Hand from Awunbarna. The black arrow points to the front legs of the horse. (Photograph: Paul S.C. Taçon, 2018.)

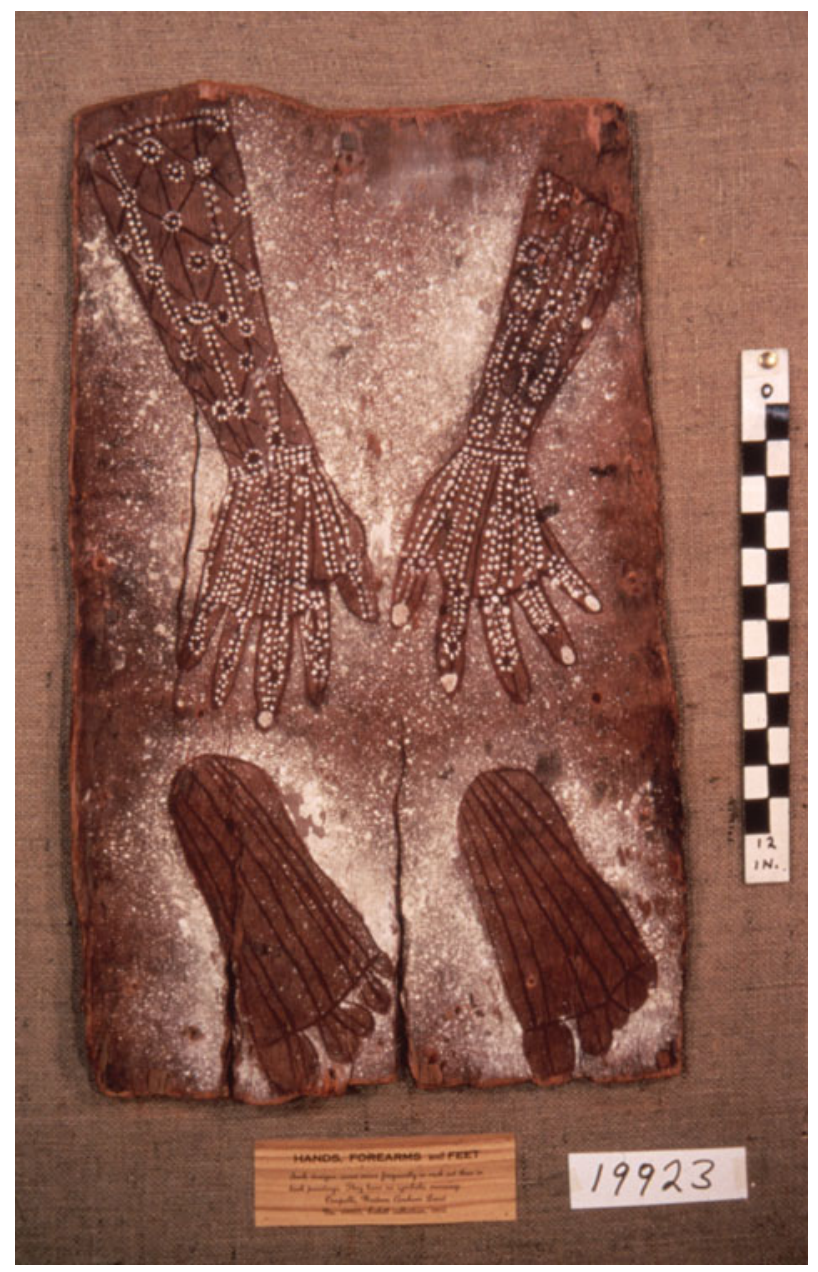

Figure 12. Bark painting collected about 1916 by Paddy Cahill in Oenpelli (Gunbalanya) and now held at Museum Victoria. (Photograph: Paul S.C. Taçon.)
Finally, a number of bark paintings collected by Paddy Cahill and sent to Baldwin Spencer around 1916 include painted hands, arms and/or feet (Fig. 12). In a letter from Cahill to Spencer accompanying a shipment of barks, he says 'I am sending you (64) sixty four copies of rock drawings, on bark, I have numbered them all, and written out their names as nearly phonetically as I can' (Cahill [1914] 2004; see also Spencer 1914, 432-3). This is important, as it tells us that there were Painted Hands in the rock art prior to 1916. The examples held today in Museum Victoria are wonderfully detailed images incorporating extensive ceremonial designs (Taylor 2015; 2016; Fig. 12).

With these many clues in mind, we suggest that Painted Hand rock art first emerged around 1900 with the establishment of more permanent settlements at Kaparlgoo and Oenpelli. The last rock-art example was most likely produced by Djimongurr in 1964, though they continue to be painted on art paper and bark by some artists today at Injalak Arts in Gunbalanya (Oenpelli). The date range for the rock art, therefore, is about 65 years, within a single generation. The timing of this rush of Painted Hands in rock art c. 1900 to $c .1964$ is important in terms of the events taking place in western Arnhem Land at this time.

\section{Contact and colonial histories}

It is important to consider the historical context of this new art style. Aboriginal engagement and cultural entanglements with outsiders in western Arnhem Land has had a long and varied history. Archaeological evidence has been growing to 
support a long period of engagement between local Aboriginal clan groups and maritime communities from island Southeast Asia from the early to mid seventeenth century (e.g. Theden-Ringl et al. 2011; Wesley et al. 2016). This long model of interaction is supported by radiocarbon dating of Macassan burials, beeswax dates over images of Macassan praus and the Anuru Bay Macassan trepang-processing site that revealed several phases of use (e.g. Taçon et al. 2010; Theden Ringl et al. 2011; Wesley et al. 2016). Macassan trepang (sea slug) processing proliferates in the latter half of the eighteenth century, continuing through to 1907 (Macknight 1976; 2011; Máñez \& Ferse 2010). Numerous ethno-historic accounts attest to substantial interaction with Aboriginal people working on praus, assisting with trepang fishing and diving, accompanied by the introduction of new materials and substantial changes in social customs and language (cf. Berndt \& Berndt 1954; Clarke 1994; Evans 1992; Ganter et al. 2006; Macknight 1986; 2011; McIntosh 1996; 2006; 2008; 2011; 2013; Mitchell 1996; 2000; Morphy 1991; Russell 2004; Warner 1932).

Following these early encounters, British attempts to colonize the north coast of Australia began in the early nineteenth century. European settlements such as Fort Wellington (1827-29) and Port Essington (1838-49) on the Cobourg Peninsula to the north and the later Escape Cliffs (1864-67) to the west of Arnhem Land all had lasting impacts on local Aboriginal populations and customary systems (e.g. Allen 1972; Evans 2000). The establishment of Port Darwin in 1869 created a nexus for incoming pastoral selectors, mining prospectors and a variety of entrepreneurs that began to exert pressure on and create conflict for Aboriginal groups in the wider region (Powell 1988; Robinson 2005; Wells 2003). This signalled the beginning of the sustained momentum of European settlement and economic development.

The European economic and social history of the Arnhem Land region is largely defined by hardship and isolation, with mining prospection, pastoral stations, buffalo-shooting enterprises, pearling, dingo scalping, crocodile hunting and timber milling predominant (e.g. Levitus 1982; 1995). Aboriginal labour was incorporated into these European enterprises (Robinson 2005). At the same time, diseases such as influenza, malaria and whooping cough (to name a few) were devastating local communities (e.g. Harris 1998, 191; Spillett 1972, 145). In short, Aboriginal people experienced regular and sustained encounters and engagement with all these European enterprises throughout the nineteenth and twentieth centuries, thereby creating multiple modes of influence, stress and conflict.

These events naturally had a severe impact on cultural practices. With the loss of life and the movement of people across the region, people were forced to re-evaluate their priorities, including commitments to ceremonial life. For example, particular ceremonies seemed to have been abandoned and new ones introduced (Berndt \& Berndt 1970, 124; Garde 2011; Thomson 1949).

\section{Distribution}

There is no doubt that Awunbarna is the epicentre for Painted Hand rock art, as also noted by Chaloupka $(1993,214)$ (Fig. 13). Our team has to date documented over 200 such paintings in the Awunbarna area, with many others yet to be properly recorded. Interestingly, despite over a decade of rock-art survey in the Wellington Range (to the north of Awunbarna), no Painted Hands have been recorded in this northern region. This is despite extensive historical-period rock art known to exist in the area (e.g. May et al. 2010; 2013; Taçon et al. 2010). To the south of Awunbarna, Minjnymirnjdawabu is home to over 40 examples recorded to date, and Nanguluwurr (Nangalore/ Nangalawur) in Kakadu has 35 surviving examples (see also Jelínek 1977; 1989; Fig. 14). Outside these hot spots, other examples have been noted on Injalak Hill near Gunbalanya as well as Burrungkuy, Koongarra, Madjedbebe (May et al. 2017a), Balawurru (Deaf Adder Gorge) (Brandl 1973; Haskovec \& Sullivan 1986; Jelínek 1989) and Amarrkanangka (Jelínek 1989; Taçon 1989b) in Kakadu.

Chaloupka $(1993,214)$ argues that, because Awunbarna is the epicentre, it must have been the Victoria Settlement (Port Essington) that inspired the Painted Hand style. While we agree that Awunbarna is the key to the story, we believe the spread of the Painted Hands tells a slightly different tale. This north-south axis of key sites suggest that no single historic place influenced the emergence of this style.

Most of the Painted Hands appear at a few key sites within these larger areas. As argued by May et al. (2017b) and Gunn et al. (2017a), historical rock art in Arnhem Land tends to cluster at key sites in the landscape. This is also true for the Painted Hands, with Madjedbebe, Nanguluwur, Minjnymirnjdawabu and Awunbarna having a significantly higher number of individual Painted Hands than anywhere else. They are all located along known historic walking routes that extend much further north towards the Cobourg Peninsula and the early British settlements in that area (e.g. Chaloupka 1981; Gunn et al. 2017b; Layton 1981). These historic routes must 


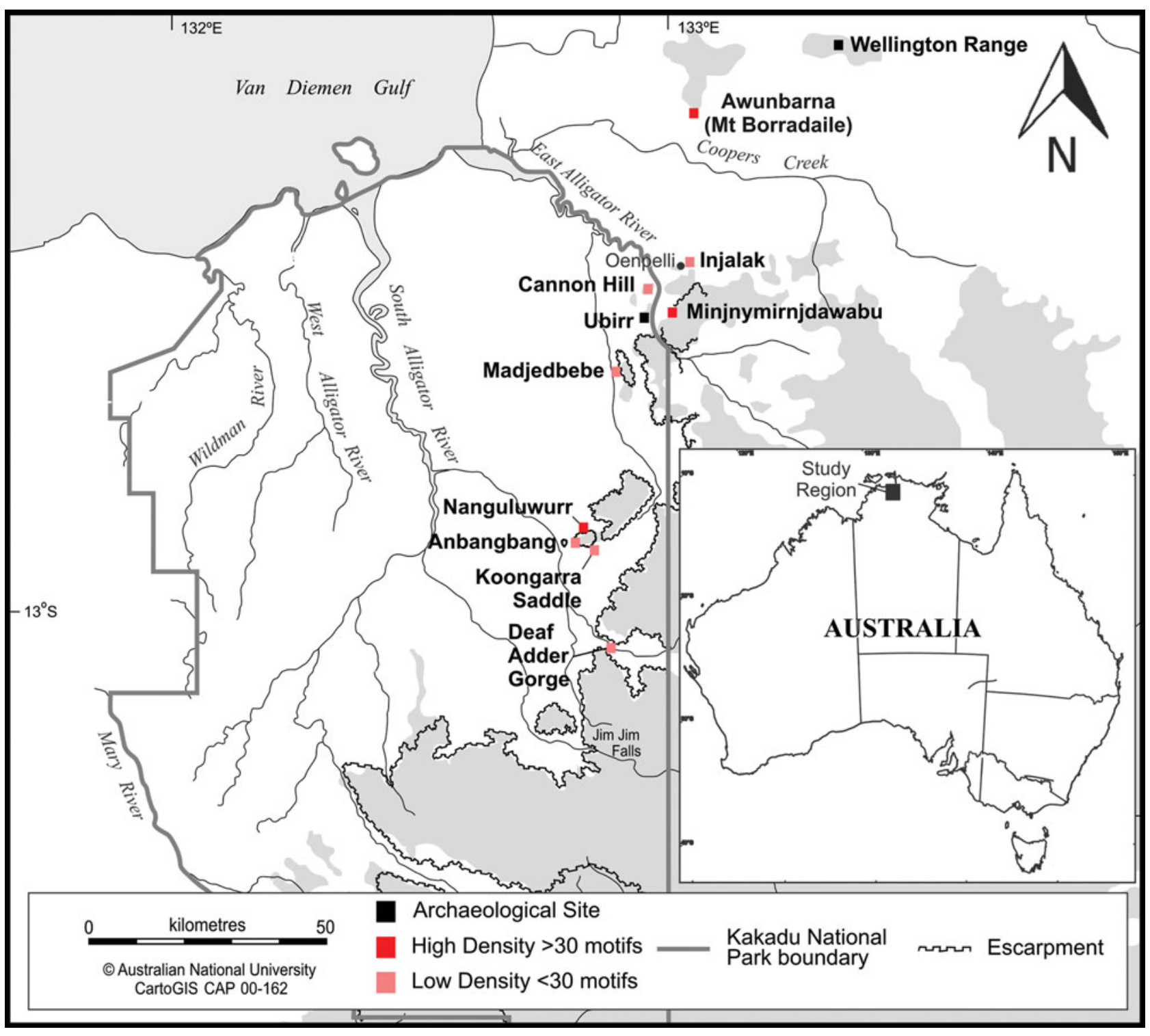

Figure 13. Location of known key Painted Hand sites. (Map: Daryl Wesley.)

have been essential for communicating information relating to this turbulent period in history (May et al. 2017a). The clusters of Painted Hands also align with other clusters of introduced imagery in rock art, such as firearms at Madjedbebe (May et al. 2017b) and sailing vessels at Awunbarna (Roberts \& Parker 2003). The Painted Hands are, therefore, part of an important communication pathway and central to the contact narrative of the time.

\section{Discussion}

The original and widely accepted interpretation of the Painted Hands is Chaloupka's (1993, 214) argument, discussed above, that they imitated the gloves worn by Europeans at early British settlements. We would argue that this interpretation is far from the truth and is, most likely, a story made up to deflect attention away from these highly significant motifs (cf. Brady et al. in press). Indeed, we are unable to share certain aspects of the interpretation due to restrictions on cultural knowledge. However, it is clear that many of the Painted Hands include designs relating directly to ceremonial activities. These designs are embedded with cultural meaning that can only be fully understood or interpreted by someone who has passed through a particular ceremony (see Taylor 1996). In this way, 


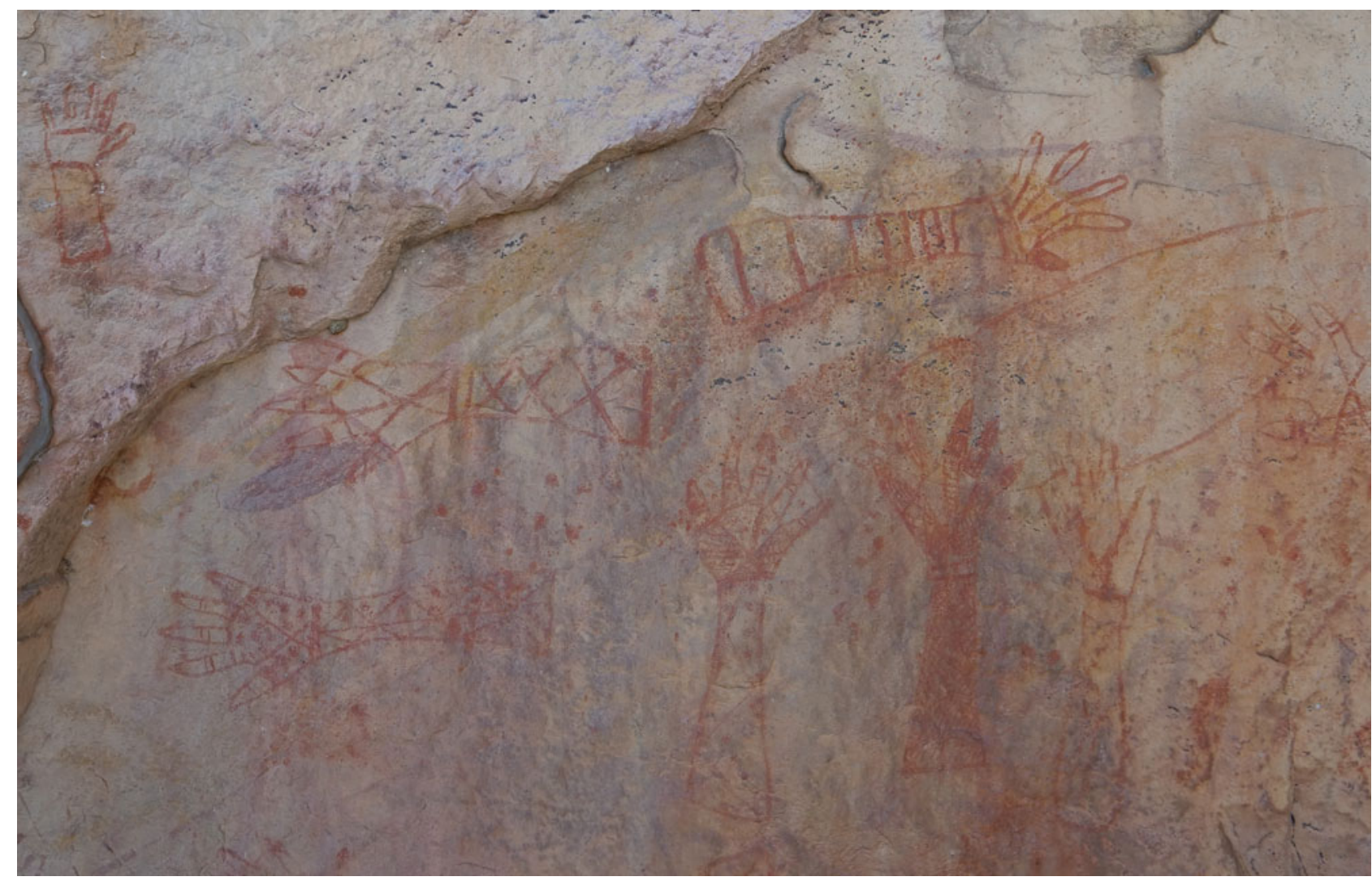

Figure 14. A selection of the Painted Hands from Nanguluwurr. (Photograph: Sally K. May, 2018.)

rock art and other forms of art from western Arnhem Land have many layers of meaning depending on who is viewing them. Figures 15 and 16 are good examples of these ceremonial designs. The designs on both the Painted Hand (Fig. 15) and the bark painting of the yam (Fig. 16) relate to ceremonial designs; initiated individuals would read into these designs far greater detail of place, person, clan, moiety and more (see Taylor 1996).

The Mardayin ceremony was one of the most important in western Arnhem Land in the early twentieth century (Berndt \& Berndt 1970). As mentioned previously, performances were strongly interlinked with other regional ceremonies in terms of initiation and mortuary cycles. Today, Mardayin is not performed as a separate ceremony, but some of its components have been melded with new, and more popular, ceremonies introduced from southern Arnhem Land. Artists continue to use imagery relating to this ceremony in their art today (Taylor 2008). As Taylor $(2016,314)$ describes, Mardayin celebrates the spiritual links between people and their originating Ancestral beings through the painting of designs called rarrk on their bodies and through being shown the sacred objects for the clan that are painted with similar designs. The designs represent important Ancestral sites in their clan lands and the act of being painted effects the physical union of the initiate with the Ancestral powers of their country. The dotted diagonal cross-shaped motifs featured on some Painted Hands echo body painting of the Mardayin ceremony, as also seen on other material culture such as men's baskets (Taylor 2016, 314-15):

The geometric frameworks of these designs include variations of diagonally crossed squares, rectangles, or triangular forms, with the inclusion of circular elements. The designs vary for different clans and the reference is a matter of ceremonial revelation. (Taylor 2008, 874).

We are using the Mardayin Painted Hands as an example-other Painted Hands include cultural and ceremonial design elements from other ceremonies, such as Wubarr and Lorrkon, which are linked with Mardayin. We are still exploring these connections with Senior Aboriginal Traditional Owners. Our point here is to emphasize that many of these Painted Hands were deliberately used during the 

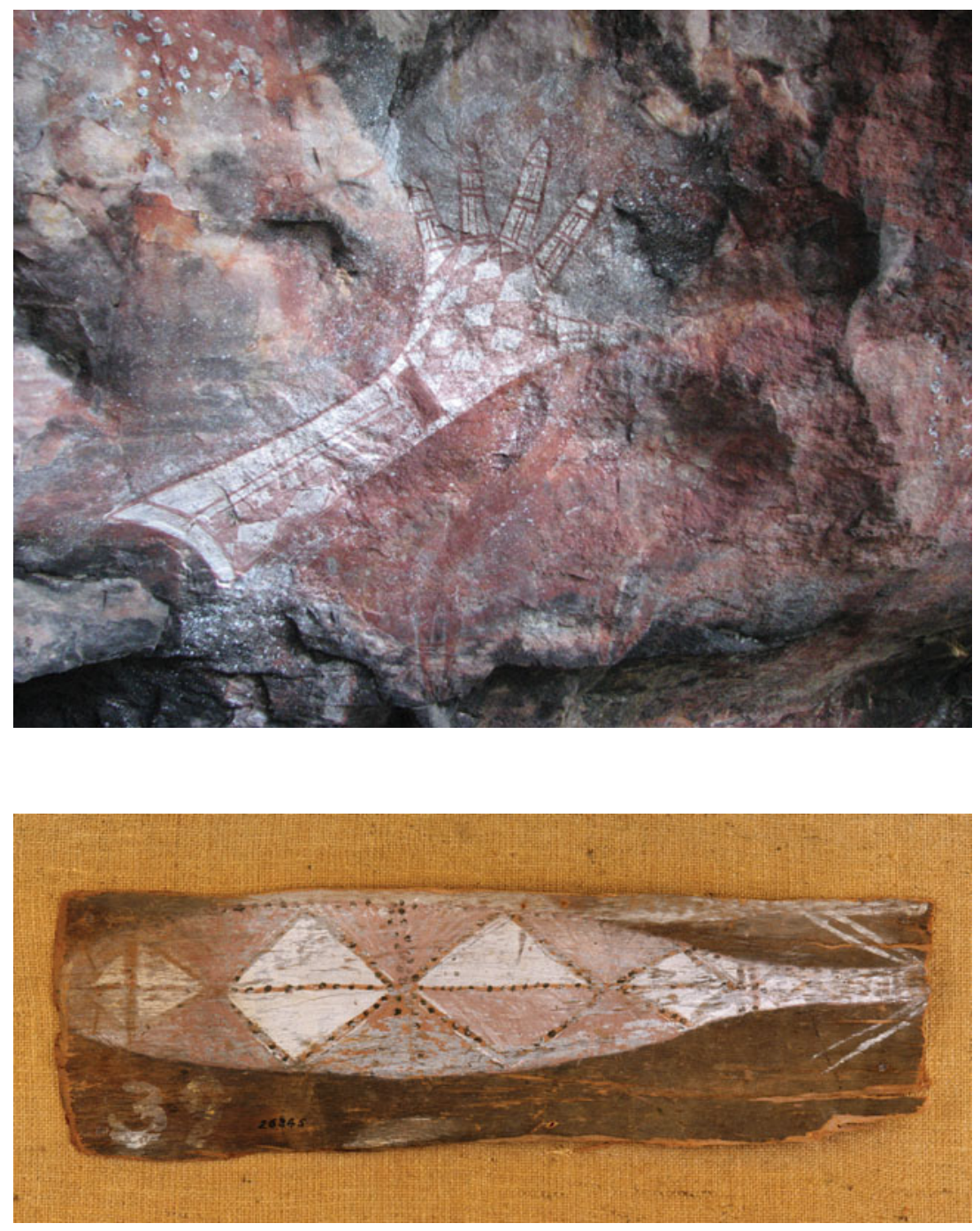

Figure 15. A Painted Hand from Minjnymirnjdawabu. (Photograph: Paul S.C. Taçon.)
Figure 16. Bark painting by an unknown artist from the Oenpelli (Gunbalanya) area collected by Paddy Cahill c. 1916 and now held at Museum Victoria. (Photograph: Paul S.C. Taçon.) recent past as a method for communicating inside ceremonial knowledge across a broad landscape. The use of the human hand to achieve this was particularly innovative: nothing like this existed before in the rock art from western Arnhem Land. The new creativity rests on combining, for the first time, a depicted hand figure, which is seen as the bodily trace of individual people who have visited a site, with geometric elaborations that identify spiritual connections between individuals and specific Ancestral country.

An important detail here is that many of the Painted Hands are encircled by single or double lines, particularly around Awunbarna. Taylor (1996) demonstrates the significance of encircling of a figure in western Arnhem Land art, in this case a bark painting produced in 1975 by artist Milaybuma:

Many paintings of fish are suggested to be 'just a fish', a fish you can find in any waterhole. However, some
Kunwinjku can paint the barramundi djang associated with Born clan lands and such works are associated with the fertilizing power of this original being. One way of indicating that the fish is djang is to include rarrk infill. Another way is to depict the fish inside a circular line as represented in the example by Milaybuma $\ldots$ This line represents the fish inside the rock at the site. Kunwinjku commonly use this means to show the djang species inside the waterhole or rock at a site. The painting of this barramundi associates the subject with ideas concerning the power of the site and the potential to use this power to ensure the increase of the species as the djang for barramundi is associated with increase rituals to ensure the renewal and plentiful supply of barramundi. (Taylor 1996, 157)

The ritual significance of encircling a figure is clearly articulated in this example and emphasizes that it is far more than a simple framing device inspired by Europeans (cf. Chaloupka 1993, 214). It is interesting 
to consider, then, how this might apply to Painted Hands and why this became a key component in this design. While the barramundi painting discussed by Taylor $(1996,157)$ is linked to increase rituals, Kuninjku use circles around a figure to indicate that the subject is djang (Ancestral creator beings) inside a particular creation site. In such cases, the circle can be read as the outline of a waterhole wherein the spiritual essence of the djang creator being still resides (see Taylor 2017, 36). Circles incorporated in Mardayin designs are usually interpreted this way by Kuninjku: they are important waterholes created by Ancestral beings where the unborn spirits of the clan reside. The souls of deceased members of the clan return here when they die and may eventually be reborn. These sites are associated with the fertilizing essence of Ancestral beings that may be released in ceremony to ensure the fertility of natural species. However, this same power can be drawn into ceremonial processes that ensure the continued rejuvenation of the clan. The Rainbow Serpent, Ngalyod, protects such places. Occasionally, in Kuninjku bark paintings and drawings, the circle can be replaced with the circular form of the Rainbow Serpent, highlighting its ubiquitous relationship with Ancestral transformation, specific clan country, site creation and sacred waters.

Frames placed around many of the Painted Hands may refer to this sacred country. The image as a whole may indicate the spiritual essence of individuals inside their sacred waters. This reading would accord with the use of frames/circles, at least by Kuninjku. As such, it could be indicating a range of ritual roles for the art and the creators of the art. Were the artists trying to indicate the ritual significance of the individual whose hand was represented? Was the production of the image intended to affect the return of their spirit to their country? Are these hands related to the rejuvenation of their clan spirit? Following his own words, Neidji's hand painting at Amarrkanangka appears to have this mortuary element. Thus, an artist who knows the identity of the creator of the original hand stencil modifies the image upon their death. The addition of the circle and geometric infill may cleanse the shelter of the deceased's lingering spirit, encouraging it to return to clan waters.

Painted Hands may be related to the dramatic loss of life in this region around 1900, a point in time when disease and murder wiped out a large proportion of the population. Indeed, Ian Keen (1980, 171) estimates the population was only 3-4 per cent of what it had been before 'contact'. At this time there were active travel routes, that incorporated rockshelters as stopping points, to newly established settlements, as well as enhanced population movements by people from the north, east, and south into depopulated lands.

Overall, it would seem that the Painted Hands are a very particular and very recent creation consistent with the themes expressed in ceremonies such as Mardayin and likely triggered by enhanced individual mobility as well as broad-based population movements post contact. It is clear that contact with balanda (non-Indigenous people) was a key motivation in the emergence of the Painted Hands. The invasion of Aboriginal lands-from missionaries, to miners, buffalo shooters and more-presented new challenges to and caused immense stress for local Aboriginal people. So are the Painted Hands a direct result of this stress? We would argue that they are, but in a more indirect way.

As discussed earlier, rock art has the remarkable ability not only to reflect periods of stress within and between different societies but also to play an active role in assisting these groups in navigating these experiences (e.g. Frieman \& May 2019). It should follow that sudden, obvious shifts in style evidenced in the archaeological record may be indicating such episodes. In the case of the Painted Hands, we would argue that they also represent a way for the moving Aboriginal families and, ultimately, populations to form attachments to new places. Just as hand stencils sometimes marked a visit to a different clan estate (e.g. Chaloupka 1993, 232), Painted Hands may reflect an attempt by visitors to establish amicable, exchange-based relationships with the Aboriginal landowners of the territory in which they found themselves post contact. In this way, the Painted Hands may have also helped to create amicable relations with neighbouring clan groups during times of population movement across the landscape.

The movement of people and ceremonies into and out of western Arnhem Land throughout the historical period is well documented (e.g. Berndt \& Berndt 1970, 124; Garde 2011, 20; Keen 1994). The exchange of ceremonies, including associated iconography, likely played a role in these movements, helping to establish these new relationships. As Garde (2011, 420) states:

Across much of Arnhem Land today, large regional ceremonial rites are regarded as important contributors to social cohesion. In my experience, such ceremonies represent important occasions for people from many disparate groups to work together for the purpose of achieving a sense of the 'corporate good'.

This idea of ceremony contributing to social cohesion is central to our argument for the emergence of the 
Painted Hands. Arising as an innovative rock-art style around 1900, the Painted Hands played a key role in the sharing of ceremonial knowledge, connecting with Ancestral beings, and the establishment of new relationships during a period of intense change.

\section{Conclusion}

The emergence of the Painted Hand rock-art style is a surprisingly recent phenomenon and reflects the experiences of Aboriginal people across western Arnhem Land from the early to mid 1900s. The humble human hand with, often, elaborate design elements represented a dialogue that would have been largely invisible to, and uninterpretable by, non-Aboriginal people. The Painted Hands represent a safe space in which to grapple with the realities of a rapidly shifting world and way of life. They were not stagnant, redundant images, but rather they played an active role in helping communities to navigate their lived experiences by constantly creating a connection between living communities and place as well as between the living, the Ancestral world and the dead. Anyone visiting these rock-shelters engaged with this imagery and re-activated their varied messages. While the original painting event or events formed a crucial aspect of their story, the cultural knowledge and personal links associated with the Painted Hands ensured they continued to play an active role in society. As one of the last major rock-art styles introduced into the rock art of western Arnhem Land, the Painted Hands represent the complexity of Australian rock art and its role in helping people to navigate the most challenging of times.

\section{Acknowledgements}

We thank the following people and organizations for sharing their time and knowledge with us: J. Galareya Namarnyilk (dec.), T. Yulidjirri (dec.), Bardayal Nadjamerrek (dec.), Donna Nadjamerrek, J. Nayinggul (dec.), Alfred Nayinggul, Connie Nayinggul and family, Jeffrey Lee, Josie Maralngurra, Christine Nabbobob, Kadeem May, Gabrielle O'Loughlin, Parks Australia, Injalak Arts, Bridget Thomson, Ray Curry, Lee Davidson, Davidson's Safari Camp and the Northern Land Council. We are grateful to Iain Johnston, John Hayward, Liam Brady, Samuel Dix, Andrea Jalandoni, Fiona McKeague and Roxanne Tsang for collaborating on fieldwork and for inspiring discussions. Thanks to John Hayward for providing the count of painted hands at Nanguluwurr and Murray Garde for advice on Aboriginal place names. SKM and PT's research is funded by the ARC grant FL160100123 'Australian rock art history, conservation and Indigenous well-being', part of Paul Taçon's ARC Laureate Project. The new recordings from Nanguluwurr, Koongarra and Burrungkuy were made as part of the 'Pathways: people, landscape and rock art' project, a collaboration with Senior Traditional Owner Jeffrey Lee, Josie Maralngurra, Christine Nabobbob and Parks Australia. Many thanks to Judy Opitz for allowing us to use her photo. CJF's participation was supported by ARC DECRA Project DE170100464. DW was supported by ARC DECRA Project DE170101447.

Sally K. May

PERAHU

Griffith Centre for Social and Cultural Research

Gold Coast campus

Griffith University, QLD 4222

Australia

Email: s.may@griffith.edu.au

Luke Taylor

Independent Researcher

Email: luketaylor982@gmail.com

Catherine Frieman

School of Archaeology and Anthropology

Australian National University

Canberra, ACT 2601

Australia

Email: catherine.frieman@anu.edu.au

Paul S.C. Taçon

PERAHU

Griffith Centre for Social and Cultural Research

Gold Coast campus

Griffith University, QLD 4222

Australia

Email: p.tacon@griffith.edu.au

Daryl Wesley

Archaeology

College of Humanities, Arts and Social Sciences

Flinders University

Sturt Road

Bedford Park, SA 5042

Australia

Email: daryl.wesley@flinders.edu.au

Tristen Jones

School of Culture, History and Language

College of Asia and the Pacific

Australian National University

Canberra, ACT 0200

Australia

Email: tristen.jones@anu.edu.au 


\author{
Joakim Goldhahn \\ Linnæus University \\ School for Cultural Sciences \\ S-391 82 Kalmar \\ Sweden \\ $\mathcal{E}$ \\ PERAHU \\ Griffith Centre for Social and Cultural Research \\ Gold Coast campus \\ Griffith University, QLD 4222 \\ Australia \\ Email: joakim.goldhahn@lnu.se \\ Charlie Mungulda \\ Senior Aboriginal Traditional Owner \\ Bunidj (Amurdak) clan \\ Awunbarna (Mt Borradaile) \\ Northern Territory \\ Australia
}

\section{References}

Allen, J., 1972. Port Essington: a successful limpet port? Historical Studies 15(59), 341-60.

Berndt, R., \& C. Berndt, 1954. Arnhem Land: Its history and its people. Melbourne: Cheshire.

Berndt, R., \& C. Berndt, 1970. Man, Land and Myth in North Australia. East Lansing (MI): Michigan State University Press.

Bijker, W.E., 1995. Of Bicycles, Bakelites, and Bulbs: Toward a theory of sociotechnical change. Cambridge (MA): MIT Press.

Brady, L., S.K. May, J. Goldhahn \& P.S.C. Taçon, in press. What painting? Encountering and interpreting the archaeological record in western Arnhem Land. Archaeology in Oceania 2020.

Brandl, E.J., 1973. Australian Aboriginal Paintings in Western and Central Arnhem Land: Temporal sequences and elements of style in Cadell River and Deaf Adder Creek art. Canberra: Australian Institute of Aboriginal Studies.

Cahill, P., [1914] 2004. Letter to Baldwin Spencer (10 June), in Paddy Cahill of Oenpelli, by J. Mulvaney. Canberra: Aboriginal Studies Press, 101.

Chaloupka, G., 1979. Survey of Sites of Significance: Nourlangie Rock Cultural Area. Unpublished report, Museum and Art Gallery of the Northern Territory, Darwin.

Chaloupka G., 1981. The traditional movement of a band of Aboriginals in Kakadu, in Kakadu National Park Education Resources, ed. T. Stokes. Canberra: Australian National Parks and Wildlife Service, 162-71.

Chaloupka, G., 1982. Burrunguy: Nourlangie Rock. Darwin: Northart.

Chaloupka, G., 1983. Back to My Country, Namarrkanga. Unpublished report to Australian National Parks and Wildlife Service, Canberra \& Darwin.
Chaloupka, G., 1985. Chronological sequence of Arnhem Land plateau rock art, in Archaeological Research in Kakadu National Park, ed. R. Jones. Canberra: Australian National Parks and Wildlife Service, 269-80.

Chaloupka, G., 1993. Journey in Time: The world's longest continuing art tradition: the 50,000 year story of the Australian Aboriginal rock art of Arnhem Land. Chatswood (NSW): Reed.

Clarke, A., 1994. Winds of Change: An Archaeology of Contact in the Groote Eylandt Archipelago, Northern Australia. Unpublished PhD thesis, Australian National University.

Collard, M., K. Vaesen, R. Cosgrove, \& W. Roebroeks, 2016. The empirical case against the 'demographic turn' in Palaeolithic archaeology. Philosophical Transactions of the Royal Society B: Biological Sciences 371(1698), 20150242.

Crown, P.L., 1994. Ceramics and Ideology: Salado polychrome pottery. Albuquerque (NM): University of New Mexico Press.

David, B. \& D. Chant, 1995. Rock art and regionalisation in North Queensland prehistory. Memoirs of the Queensland Museum 37(2), 357-528.

David, B. \& H. Lourandos, 1998. Rock art and sociodemography in northeastern Australian prehistory. World Archaeology 30(2), 193-219.

David, B. \& H. Lourandos, 1999. Landscape as mind: land use, cultural space and change in north Queensland prehistory. Quaternary International 59, 107e123.

Dowson, T.A., 1994. Reading art, writing history: rock art and social change in southern Africa. World Archaeology 25, 332-45.

Evans, N., 1992. Macassan loanwords in Top End languages. Australian Journal of Linguistics 12(1), 45-91.

Evans, N., 2000. Iwaidjan, a very un-Australian language family. Linguistic Typology 4(2), 91-142.

French, J.C., 2016. Demography and the Palaeolithic archaeological record. Journal of Archaeological Method and Theory 23(1), 150-99.

Frieman, C.J., in prep. An Archaeology of Innovation. Manchester University Press.

Frieman, C.J. \& S.K. May, 2019. Navigating contact: tradition and innovation in Australian contact rock art. International Journal of Historical Archaeology. https://doi.org/10.1007/s10761-019-00511-0

Ganter, R., J. Martinez, \& G. Lee, 2006. Mixed relations: Asian-Aboriginal contact in North Australia. Crawley: University of Western Australia Press.

Garde, M., 2011. The forbidden gaze: the 1948 Wubarr ceremony performed for the American-Australian Scientific Expedition to Arnhem Land, in Exploring the Legacy of the 1948 Arnhem Land Expedition, eds M. Thomas \& M. Neale. Canberra: ANU Press, $403-21$.

Goldhahn, J. \& S.K. May, 2019. Beyond the colonial encounter: global approaches to contact rock art studies. Australian Archaeology 86, 210-18.

Gunn, R., B. David, R. Whear, et al., 2017a. Postcards from the outside: European-contact rock art imagery and 
occupation on the southern Arnhem Land plateau, Jawoyn lands, in The Archaeology of Rock Art in Western Arnhem Land, Australia, eds B. David, P.S. C. Taçon, J.J. Delannoy \& J.M. Geneste. (Terra Australis 47.) Canberra: ANU Press, 165-97.

Gunn, R., L. Douglas \& R. Whear, 2017b. Art islands on the plateau: rock art site complexes in the Jawoyn Lands of the Arnhem Land Plateau. Australian Archaeology 83(3), 110-26.

Harris, N., 1998. Wish We'd Done More: Ninety years of CMS and Aboriginal issues in north Australia. Adelaide: Openbook.

Haskovec, I.P., \& H. Sullivan, 1986. Najombolmi. The Life and Work of an Aboriginal Artist. A report to the Australian National Parks and Wildlife Service, Darwin.

Haskovec, I.P., \& H. Sullivan, 1989. Reflections and rejections of an Aboriginal artist, in Animals into art ed. H. Morphy. (One world archaeology volume 7) London: Unwin Hyman, 57-74.

Henrich, J., 2004. Demography and cultural evolution: how adaptive cultural processes can produce maladaptive losses-the Tasmanian case. American Antiquity 69 (2), 197-214.

Hodder, I., 1979. Economic and social stress and material culture patterning. American Antiquity 44(3), 446-54.

Jelínek, J., 1976. The social meaning of north Australian rock paintings. Anthropologie 14(1), 83-7.

Jelínek, J., 1977. Nangalore: a gallery of rock paintings in western Arnhem Land. Anthropologie 15(1), 3-26.

Jelínek, J., 1989. The Great Art of the Early Australians: A study of the evolution and role of rock art in the society of Australian hunters and gatherers. Prague: Moravian Museum Brno-Anthropos Institute.

Jones, R., 1985. Archaeological conclusions, in Archaeological Research in Kakadu National Park, ed. R. Jones. Canberra: Australian National Parks and Wildlife Service, 291-8.

Keen, I., 1980. The Alligator Rivers Stage II Land Claim. Unpublished manuscript, Northern Land Council, Darwin.

Keen, I., 1994. Knowledge and Secrecy in an Aboriginal Religion. Oxford: Clarendon Press.

Layton, R., 1981. Statement on the Alligator Rivers Stage Two Land Claim: (1) Traditional Foraging and Camping Patterns; (2) Rock Paintings. Unpublished report for the Northern Land Council, Darwin.

Layton, R., 1992. Australian Rock Art: A new synthesis. Cambridge: Cambridge University Press.

Lemonnier, P., 1992. Elements for an Anthropology of Technology. Ann Arbor (MI): University of Michigan Museum of Anthropology.

Levitus, R., 1982. Everybody Bin All Day Work: A report on the social history of the Alligator Rivers Region of the Northern Territory 1869-1973. Canberra: Australian Institute of Aboriginal Studies.

Levitus, R., 1995. Social history since colonisation, in Kakadu: Natural and cultural heritage management, eds T. Press, D. Lea, A. Webb \& A. Graham. Darwin:
Australian Nature Conservation Agency/North Australia Research Unit, 64-93.

Macknight, C.C., 1976. The Voyage to Marege. Macassan trepangers in northern Australia. Melbourne: Melbourne University Press.

Macknight, C.C., 1986. Macassans and the Aboriginal past. Archaeology in Oceania, 21, 69-75.

Macknight, C.C., 2011. 'The view from Marege': Australian knowledge of Makassar and the impact of the trepang industry across two centuries. Aboriginal History 35, 121-43.

Máñez, K.S. \& S.C. Ferse, 2010. The history of Makassan trepang fishing and trade. PloS One 5(6): e11346.

May, S.K., J. Maralngurra, I.G. Johnston, et al., 2019. 'This is my father's painting': a first-hand account of the creation of the most iconic rock art in Kakadu National Park. Rock Art Research 36(2), 199-213.

May, S.K., P.S.C. Taçon, D. Guse \& M. Travers, 2010. Painting history: Indigenous observations and depictions of the 'Other' in northwestern Arnhem Land, Australia. Australian Archaeology 71(1), 57-65.

May, S.K., P.S.C. Taçon, A. Paterson \& M. Travers, 2013. The world from Malarrak: depictions of Southeast Asian and European subjects in rock art from the Wellington Range, Australia. Australian Aboriginal Studies 2013(1), 45-56.

May, S.K., P.S.C. Taçon, D. Wright, M. Marshall, J. Goldhahn \& I. Domingo Sanz, 2017a. The rock art of Madjedbebe (Malakunanja II), in The Archaeology of Rock Art in Western Arnhem Land, Australia, eds B. David, P.S.C. Taçon, J.J. Delannoy \& J.M. Geneste. (Terra Australis 47.) Canberra: ANU Press, 87-107.

May, S.K., D. Wesley, J. Goldhahn, M. Litster, B. Manera, 2017b. Symbols of power: the firearm paintings of Madjedbebe (Malakunanja II). International Journal of Historical Archaeology 21(1), 690-707.

McIntosh, I.S., 1996. Islam and Australia's Aborigines? A perspective from north-east Arnhem Land. Journal of Religious History 20(1), 53-77.

McIntosh, I.S., 2006. A treaty with the Macassans? Burrumarra and the Dholtji ideal. Asia Pacific Journal of Anthropology 7(2), 153-72.

McIntosh, I.S., 2008. Pre-Macassans at Dholtji? Exploring one of north-east Arnhem Land's great conundrums, in Strangers on the Shore: Early coastal contacts in Australia, eds P. Veth, P. Sutton \& M. Neale. Canberra: National Museum of Australia, 165-80.

McIntosh, I.S., 2011. Missing the Revolution! Negotiating disclosure on the pre-Macassans (Bayini), in Exploring the Legacy of the 1948 Arnhem Land Expedition, eds M. Thomas \& M. Neale. Canberra: ANU Press, 337-54.

McIntosh, I.S., 2013. Unbirri's pre-Macassan legacy, or how the Yolngu became black, in Macassan History and Heritage: Journeys, encounters and influences, eds M. Clark \& S. May. Canberra: ANU E Press, 95-105.

Mitchell, S., 1996. Dugongs and dugouts, sharptacks and shellbacks: Macassan contact and Aboriginal marine hunting on the Coburg Peninsula, north-western 
Arnhemland. Bulletin of the Indo-Pacific Prehistory Association 2(15), 181-91.

Mitchell, S., 2000. Guns or barter? Indigenous exchange networks and the mediation of conflict in postcontact western Arnhem Land, in The Archaeology of Difference. Negotiating cross-cultural engagements, eds R. Torrence \& A. Clarke. Hoboken: Routledge, 182-214.

Morphy, H., 1991. Ancestral Connections: Art and an Aboriginal system of knowledge. Chicago (IL): University of Chicago Press.

Morwood, M.J., 2002. Visions from the Past. Washington (DC): Smithsonian Institution Press.

Mountford, C.P., 1956. Records of the American-Australian Scientific Expedition to Arnhem Land, Vol. 1: Art, Myth and Symbolism. Melbourne: Melbourne University Press.

Mulvaney, K., 2018. Murujuga at a crossroads: considering the evidence of nineteenth-century contact, Dampier Archipelago, northwest Australia. Australian Archaeology 84(3), 248-62.

Pfaffenberger, B., 1992. Social anthropology of technology. Annual Review of Anthropology 21(1), 491-516.

Powell, A., 1988. A Far Country: A short history of the Northern Territory. Melbourne: Melbourne University Press.

Powell, A., S. Shennan \& M.G. Thomas, 2009. Late Pleistocene demography and the appearance of modern human behavior. Science 324(5932), 1298-301.

Roberts, D.A., 2004. Nautical themes in the Aboriginal rock paintings of Mount Borradaile, western Arnhem Land. Great Circle: Journal of the Australian Association for Maritime History 26(1), 19-50.

Roberts, D.A. \& A. Parker, 2003. Ancient Ochres: The Aboriginal rock paintings of Mount Borradaile. Marleston: J.B. Books.

Robinson, C.J., 2005. Buffalo hunting and the feral frontier of Australia's Northern Territory. Social $\mathcal{E}$ Cultural Geography 6(6), 885-901.

Rogers, E.M., 2003. Diffusion of Innovations (5th edn). London: Free Press.

Rogers, E.M. \& F.F. Shoemaker, 1971. Communication of Innovations: A cross-cultural approach (2nd edn). New York (NY): Free Press.

Ross, J., 2013. A continent of nations: the emergence of regionally distinct rock art styles across Australia. Quaternary International 285, 161-71.

Russell, D., 2004. Aboriginal-Makassan in the eighteenth and nineteenth centuries in northern Australia and contemporary sea rights claims. Australian Aboriginal Studies 2004(1), 3-17.

Shennan, S., 2001. Demography and cultural innovation: a model and its implications for the emergence of modern human culture. Cambridge Archaeological Journal 11(1), 5-16.

Spencer, B., 1914. The Native Tribes of the Northern Territory of Australia. London: Macmillan.

Spillett, P., 1972. Forsaken Settlement: An illustrated history of the settlement of Victoria, Port Essington north Australia 1838-1849. Melbourne: Lansdowne.
Taçon, P.S.C., 1989a. From Rainbow Snakes to 'X-ray' Fish: The Nature of the Recent Rock Painting Tradition of Western Arnhem Land, Australia. Unpublished PhD thesis, Australian National University. Volume 1 (text).

Taçon, P.S.C., 1989b. From Rainbow Snakes to 'X-ray' Fish: The Nature of the Recent Rock Painting Tradition of Western Arnhem Land, Australia. Unpublished PhD thesis, Australian National University. Volume 2 (photographs).

Taçon, P.S.C., M. Kelleher, G. King \& W. Brennan, 2008. Eagle's Reach: a focal point for past and present social identity within the Northern Blue Mountains World Heritage Area, Australia, in Archaeologies of Art: Time, place, and identity, eds. I. Domingo Sanz, D. Fiore \& S.K. May. Walnut Creek (CA): Left Coast Press, 195-214.

Taçon, P.S.C., S.K. May, S.J. Fallon, M. Travers, D. Wesley \& R. Lamilami, 2010. A minimum age for early depictions of Southeast Asian praus in the rock art of Arnhem Land, Northern Territory. Australian Archaeology 71(1), 1-10.

Taçon, P.S.C., A. Paterson, J. Ross \& S.K. May, 2012. Picturing change and changing pictures: contact period rock art of Australia, in A Companion to Rock Art, eds. J. McDonald \& P. Veth. Chichester: Blackwell, 420-36.

Taylor, L., 1996. Seeing the Inside: Bark painting in western Arnhem Land. Oxford: Oxford University Press.

Taylor, L., 2008. 'They may say tourist, may say truly painting': aesthetic evaluation and meaning of bark paintings in western Arnhem Land, northern Australia. Journal of the Royal Anthropological Institute 14(4), 865-85.

Taylor, L., 2015. Categories of 'Old' and 'New' in Western Arnhem Land bark painting, in Long History Deep Time, eds. A. McGrath \& M.A. Jebb. Canberra: ANU Press, 101-17.

Taylor, L., 2016. Recent art history in rock country: bark painters inspired by rock paintings, in Relating to Rock Art in the Contemporary World: Navigating symbolism, meaning, and significance, eds L. Brady \& P.S. C. Taçon. Boulder (CO): University Press of Colorado, 307-36.

Taylor, L., 2017. Drawings about Djang: drawings on paper by Jimmy Bireyula, 1983. Australian Aboriginal Studies 2017(1), 28-43.

Theden-Ringl, F., J.N. Fenner, D. Wesley \& R. Lamilami, 2011. Buried on foreign shores: isotope analysis of the origin of human remains recovered from a Macassan site in Arnhem Land. Australian Archaeology 73(1), 41-8.

Thomson, D.F., 1949. Economic Structure and the Ceremonial Exchange Cycle in Arnhem Land (Vol. 9). Melbourne: Macmillan.

Torrence, R. \& S.E. van der Leeuw, 1989. Introduction: What's new about innovation?, in What's New? A closer look at the process of innovation, eds. S.E. van der Leeuw \& R. Torrence. London: Unwin Hyman, 1-15.

Troncoso, A. \& F. Vergara, 2013. History, landscape, and social life: rock art among hunter-gatherers and 
farmers in Chile's semi-arid north. Time and Mind 6, 105-12.

Vaesen, K., M. Collard, R. Cosgrove, \& W. Roebroeks, 2016. Population size does not explain past changes in cultural complexity. Proceedings of the National Academy of Sciences 113(16), E2241-7.

Veth, P., C. Myers, P. Heaney \& S. Ouzman, 2018. Plants before farming: the deep history of plant-use and representation in the rock art of Australia's Kimberley region. Quaternary International 489, 26-45.

Warner, W.L., 1932. Malay influence on the Aboriginal cultures of North-Eastern Arnhem Land. Oceania 2(4), 476-95.

Wells, S., 2003. Negotiating Place in Colonial Darwin Interactions Between Aborigines and Whites, 18691911. Unpublished $\mathrm{PhD}$ thesis, University of Technology, Sydney.

Wesley, D., S. O'Connor \& J.N. Fenner, 2016. Re-evaluating the timing of the Indonesian trepang industry in north-west Arnhem Land: chronological investigations at Malara (Anuru Bay A). Archaeology in Oceania 51(3), 169-95.

Wiessner, P., 1983. Style and social information in Kalahari San projectile points. American Antiquity 48(2), 253-76.

\section{Author biographies}

Sally K. May is a Senior Research Fellow with the Place, Evolution and Rock Art Heritage Unit (PERAHU) at Griffith University. As an archaeologist and anthropologist, her research focuses on relationships between people, landscapes, material culture and imagery, with inspiration drawn primarily from fieldwork in northern Australia.

Luke Taylor is an anthropologist who has worked in western Arnhem Land since 1981. His primary research is published in Seeing the Inside (Clarendon Press, 1996). He was a Senior Curator at the National Museum of Australia 19912000 and Director of Research and Deputy Principal of AIATSIS 2000-2013. In the same period he was Adjunct Professor at the Australian National University, Canberra.
Catherine J. Frieman obtained her DPhil from the University of Oxford in 2011. She is currently a senior lecturer in European Archaeology at the Australian National University. Her research interests include the nature of archaeological inquiry, archaeological material culture and technology, innovation and mobility studies, skeuomorphism, flint daggers, and the beginning of the Metal Ages.

Paul S.C. Taçon FAHA FSA is an ARC Australian Laureate Fellow (2016-2021), Chair in Rock Art Research and Director of Griffith University's Place, Evolution and Rock Art Heritage Unit. Archaeological and ethnographic fieldwork since 1980 has led to over 270 academic publications on rock art, cultural heritage and human evolution.

Daryl Wesley is a Research Fellow at Flinders University. Practising as a multidisciplinary archaeologist, he has conducted projects in field archaeology, rock art, archaeological sciences, heritage conservation and anthropological research in northern Australia.

Tristen Jones is an archaeologist, historian and curator, with expertise and research interests in Australian rock art, cultural heritage management and indigenous engagement practice in the cultural heritage sector, prehistoric modern symbolic behaviours, the history of archaeology, and Australian Indigenous and Pacific museum collections.

Joakim Goldhahn is a professor in Archaeology at Linnæus University, Sweden and an adjunct Research Fellow at PERAHU, Griffith University, Australia. His research focuses on North European Bronze Age, rock art as a meaning-creating phenomenon, burial rituals, ritual specialists, war, and more.

Charlie Mungulda is a Senior Traditional Owner for the Awunbarna area. He is a member of the Bunidj (Amurdakspeaking) clan and the last speaker of the Amurdak language. Now in his 80s, Charlie has spent his life on Country and is a senior law man and ceremonial leader. 